\title{
Newspaper reporting of the April 2007 eruption of Piton de la Fournaise part 1: useful information or tabloid sensationalism?
}

\author{
Andrew J. L. Harris ${ }^{1 *}$ and Nicolas Villeneuve ${ }^{2,3}$
}

\begin{abstract}
During March, April and May 2007 the local newspaper for the island of La Réunion, "Le Journal de L'lle de La Réunion" (JIR), published 427 articles relating to natural hazards, with hazard-related articles occupying a total paper area of $21.94 \mathrm{~m}^{2}$ and appearing in all but four of the 90 editions of the newspaper. This high level of coverage was due to the passage of two cyclones in March, the largest historical eruption of Piton de la Fournaise in April, and a major rock fall event in May. The high level of coverage may also be due to the fact that JIR is a tabloid that follows tabloid news values. Cyclones, volcanic eruptions and rock falls fit the news values of a tabloid well, especially when the stories involve the power elite, feature stories of human interest, include surprise elements and rescues, and are of high impact, especially to the local population. Disasters also provide spectacular imagery and the opportunity for eye-catching headlines, which is another element of the tabloid format. These key parameters thus all flag stories about natural hazards and, in particular, volcanic eruptions as being newsworthy for a tabloid. Of the page space devoted to natural hazards, $9.24 \mathrm{~m}^{2}$ (42\%) were set aside to reporting of volcanic activity, specifically the April 2007 eruption of Piton de la Fournaise. We completed a content analysis of these reports to understand the quality of information disseminated to the readership and to extract data regarding the impact of the eruption on local communities. We found the information to be of extremely high quality, with lava reporting being the most important issue covered by page area, mostly due to its photogenic nature. If we consider textdominated reports, and exclude photo-montages, then the order of importance in terms of space set aside to reporting of a particular theme becomes: (i) general eruption details; (ii) summit collapse; (iii) lava flows; (iv) evacuation; (v) gas; (vi) ocean-entry; (v) air fall; (vi) vegetation fires (lit by lava contact); and (vii) volcano-seismicity. As the eruption and the nature of the hazard evolved (from lava flow through air-fall and gas, to summit collapse and ocean-entry) so too did the focus of the reporting. Once the eruption had finished, emphasis shifted from the hardships of the impacted community to sightseeing and tourism. We found that the quality of the reporting resulted from the use of journalists who were specialized in their reporting areas and who therefore knew the background and the correct sources to seek out for information. This shows that a well-informed journalist can be (i) a means to disseminate information and educate an impacted population, and (ii) a source of information for the volcanologist regarding societal impacts of, and population responses to, natural hazards.
\end{abstract}

Keywords: Newspaper, Tabloid, News values, Science reporter, Volcanic eruption, Content analysis, Hazard, Impact

\footnotetext{
* Correspondence: andrew.harris@uca.fr

'Université Clermont Auvergne, CNRS, IRD, OPGC, Laboratoire Magmas et

Volcans, 6 Avenue Blaise Pascal, 63178 Aubière, France

Full list of author information is available at the end of the article
} 


\section{Introduction}

The local newspaper can be regarded as an enormous database (Mathien 1986) that contains information regarding the type, location, time and duration of natural hazards occurring in the newspaper's catchment (e.g., Guzzetti et al. 1995, 2003; Hilker et al. 2009; Petrucci et al. 2010). The newspaper content also contains details regarding damage and loss. As a result, Russell Blong's source book on volcanic hazard (Blong 1984), for example, draws heavily on information contained in newspaper reports to document societal impacts of eruptive events. The newspaper also records scientific, governmental, service-provider, responder, and community actions, responses and reactions during a volcanic emergency (Harris et al. 2012). However, agenda-setting, spin and framing are all part of creating the news (Cohen, 1963; McCombs and Shaw 1972; McCombs 2014a, b; Vu et al. 2014). The result is exaggeration and omission so as to set the agenda, as well as to introduce bias through placement of material, use of source, selection of data and preference of data use (Harris 2015a). We also need to be wary of the quality, reliability and validity of information introduced to the data as it flows from its sources, through the newspaper 'filter', to the reader (Harris 2015a), and be aware of error and credibility (Maier 2005). The overall result is the question: does the newspaper provide a realistic or sensationalist information source?

The credibility problem has become worse over the last 40 years due to the entrenchment of the tabloid culture (e.g., Conboy 2011; Davies 2009; Watson and Hickham 2010). The tabloid format has been defined by Conboy (2004) as involving an increase in news about "celebrities, entertainment, lifestyle features, personal issues", an increase in "sensationalism" and a convergence on agendas of "popular" and, in particular, "television" culture; which are all placed in an "easy-to-consume" format (Rooney 2000). Because many newspapers now follow this format, this will mean that today:

i. Space devoted to reporting tabloid news values will be maximized at the expense of space devoted to reporting of public affairs (Conboy 2004), and

ii. Issues of exaggeration, placement, selection, preference, as well as objectivity, accuracy, error and credibility will have to be carefully assessed (Harris 2015a).

On the positive side, because a natural hazard is a sensational event which suits the "sledgehammer headline, big photograph" with "human interest story" format of the tabloid (Horrie 2003), we may find greater quantities of reporting on high-impact and spectacular natural hazard events in the tabloid.
Content analysis is a means to complete an "objective, systematic, and quantitative description" of an event (Berelson 1952, p. 18), thereby allowing extraction of facts from the media content (Neuendorf 2002). We refer the reader to Neuendorf 2002 for an authoritative definition of content, content analysis, its inherent methodologies and types of data that can be extracted, as well as the classic texts of Holsti (1969), Krippendorff (1980) and Weber (1990). We here carry out a content analysis that involves implementation of a three-step methodology that allows newspaper content to be analyzed and used during a disaster (specifically, a volcanic eruption). In step 1 we define the quantity, type, and quality of information delivered, allowing an assessment of the effectiveness of the source as a means of correctly communicating and retrieving information regarding the natural hazard, as well as event impact and response. In this regard, media reporting can be viewed as a key means to educate a population allowing it to better prepare for, and respond to, a natural hazard (Coppola 2015). In step 2, we assess whether the newspaper format is tabloid. From the point-of-view of the volcanologist this is important because, if a volcanic event is deemed newsworthy for the tabloid, then the event will be reported, and hence information will be disseminated. Finally, in step 3, we use the newspaper content to build a database regarding the impacts of the event on the impacted population, as was done for example by Blong (1984) for volcanic hazards and by Sterling (1997) and Séchet (2004) for weather-related hazards, thereby creating a timeline for the societal impacts of the natural hazard. Understanding how information is filtered and represented informs on how we can interact with the media to maximize the effectiveness, and correctness, of the message delivered.

To complete our analysis we selected three months of reporting in "Le Journal de L'Ile de La Réunion" (JIR) before, during and after the April 2007 eruption of Piton de la Fournaise (La Réunion, France). Founded in 1951, JIR currently costs 1.2 euro and is widely available across La Réunion (https://www.clicanoo.re/). JIR's main competitor is Le Quotidien (http://www.lequotidien.re/), which also costs 1.2 euro and was founded in 1976. Unfortunately, neither newspaper is part of the Alliance pour les Chiffres de la Presse et des Medias (ACPM), the French agency responsible for collating newspaper readership statistics (http://www.acpm.fr/Chiffres), so we have no figures for the distribution of these two newspapers. We selected the April 2007 eruption because it was the most important historic eruption of Piton de la Fournaise in terms of magnitude and intensity (Staudacher et al. 2009), it presented an array of volcanic hazards (lava flows, air fall, gas, ocean entry of lava flows and bench collapse, and pit crater collapse), and it resulted in evacuation of the village of Le Tremblet (Fig. 1). 


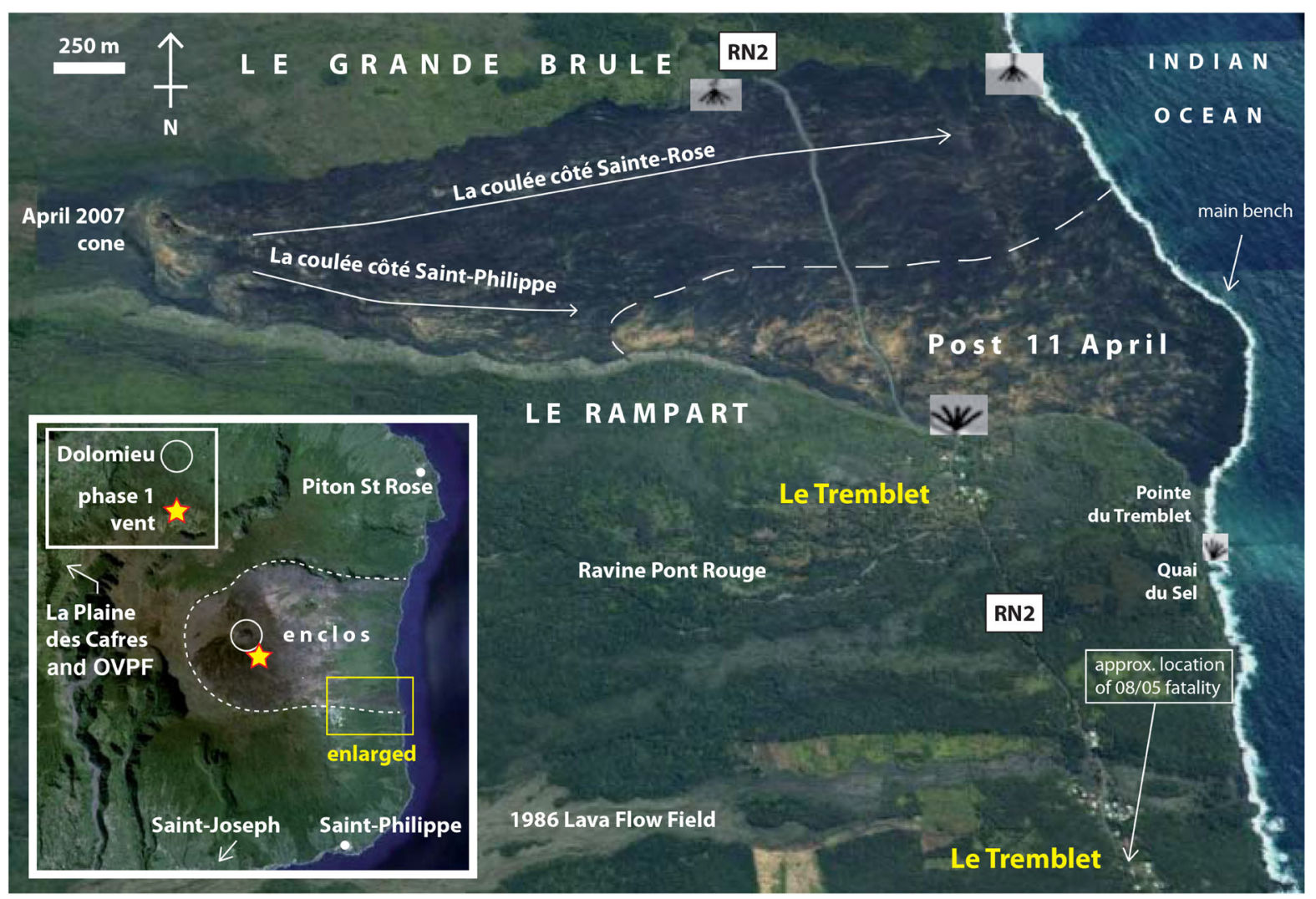

Fig. 1 Google Earth image of the 2007 flow field with all locations referred to in the text. Image is from 31/12/2008 (Image: NASA) and includes locations of the four controlled viewing points opened up on 4 April 2007, as announced in JIR on 5 (p. 9) and 6 April (P. 7). Inset is a Piton de la Fournaise location map on a Google Earth (@ 2015 Google) image (Image @ 2015 Digital Globe); data: SIO, NOAA, U.S. Navy, NGA, GEBCO. Labelling of 'L'Enclos' is based on the geographical location terms used by the newspapers and locals and refers to the entire caldera. It thus includes L'Enclos Fouqué (upper part of the caldera), Les Grandes Pentes (middle part) and Le Grand Brûlé (coastal part)

The eruption also occurred alongside other high impact hazards including the passage of a tropical cyclone in March and a rock fall event in May that (like the eruption) blocked the island belt road, this being "Route National 2" (RN2) - the main road that parallels the coast around the island and which links all coastal communities. Herein we use the acronym OVPF for the Observatoire Volcanologique du Piton de la Fournaise, the volcano observatory charged with monitoring Piton de la Fournaise (Harris et al. 2017), and all locations are marked on Fig. 1.

\section{Natural hazards impacting La Réunion during March-May 2007}

The April 2007 eruption was the largest historical eruption of Piton de la Fournaise. It had a sub-aerial lava volume of $110-140 \times 10^{6} \mathrm{~m}^{3}$ and a near-shore submarine volume of $90 \times 10^{6} \mathrm{~m}^{3}$ (Bachèlery et al. 2010), with the 29.6 day eruption duration (Roult et al. 2012) giving a mean output rate $84 \pm 6 \mathrm{~m}^{3} \mathrm{~s}^{-1}$ (Rhéty et al. 2017). The April eruption was the third eruptive event of 2007, the first event having occurred during 18-19 February.
The February eruption lasted nine hours during which time $0.4 \times 10^{6} \mathrm{~m}^{3}$ of lava was erupted, largely into the floor of the Dolomieu crater (Fig. 1), with a small lava flow being emplaced high on Dolomieu's east flank (Staudacher et al. 2008). A second event began on 30 March from an eruptive fissure located on the SE flank of the Dolomieu cone, at $1900 \mathrm{~m}$ above sea level (asl) (Fig. 1). This event lasted $10 \mathrm{~h}$ and emitted less than $106 \mathrm{~m}^{3}$ of lava (Staudacher et al. 2008; Roult et al. 2012).

The third eruptive event of 2007 began on 2 April at 10:00 (all times are local: GMT +4 ) from a point $300 \mathrm{~m}$ from the southern edge of the Enclos Fouque caldera at $590 \mathrm{~m}$ asl (Staudacher et al. 2008). This event is today recognized as the re-activation of the 30 March event (Roult et al. 2012; Froger et al. 2015). Lava began to enter the ocean ( $3 \mathrm{~km}$ from the vent) $11.5 \mathrm{~h}$ after the beginning of the eruption (Staudacher et al. 2009), with channel-fed flows of 'a'a cutting the RN2 (2 km from the vent) at 15:15 (Staudacher et al. 2008). Eruption intensity reached a maximum on 6 April when lava fountains reached $200 \mathrm{~m}$ in height, effusion rates peaked at $200 \mathrm{~m}^{3} \mathrm{~s}^{-1}$ (Staudacher et al., 2009), and channel-fed 
lava flow extended to the ocean where they began to build a bench (Fig. 1). The final 16 days of effusion involved emplacement of channel-fed 'a'a on the south-eastern side of the flow field at lower effusion rates (Rhéty et al. 2017) and diminished gas fluxes (Tulet and Villeneuve 2011). After 14 April a lava tube also became well-established down the southern margin of the flow field close to the caldera wall (Rhéty et al. 2017). This fed ocean-entry lava flow continuously until the end of the eruption (Staudacher et al. 2009). Activity continued in this style until 20:00 on 1 May, when the eruption ended, the thickness of the lava flow field over the RN2 having reached $50 \mathrm{~m}$ (Staudacher et al. 2009).

La Réunion was also impacted by three cyclones, flash floods, high waves, landslides and rock falls in the months before and after the April 2007 eruption. Classified as a tropical cyclone, the equivalent of a category 1-to-2 hurricane (Burt 2007), Gamède made two approaches to the island of La Réunion. During the first passage on 24 February, Gamède passed around $200 \mathrm{~km}$ northwest of the island bringing heavy rains and winds that peaked at $167 \mathrm{~km} / \mathrm{h}$ (Météo-France 2007). The second passage occurred on 27 February when Gamède moved to a position $250 \mathrm{~km}$ west of the island while the cyclone was moving south. Only on the morning of 28 February did conditions improve across the island as the system moved away to the southwest (Quetelard et al. 2008). The maximum 24-h rainfall recorded on the island during Gamède's passage was $1625 \mathrm{~mm}$, with the 48-h amount of $2463 \mathrm{~mm}$ being just $3 \mathrm{~mm}$ short of the world record, and the 72-h amount $(3929 \mathrm{~mm}$ ) breaking the world record by $689 \mathrm{~mm}$ (Météo-France 2007). Damage was major and widespread:

- The main-road bridge linking Saint-Louis-SaintPierre and the north of the island was washed out (Verrière 2007);

- Numerous other roads were cut by flooding (JIR, 26 February 2007, no. 18,312, p. 9);

- Electricity, water, and phone lines were cut for 80,000 households (Técher 2007);

- The airport was closed and all flights grounded (Dupuis 2007a); and

- Two deaths were recorded (JIR, 1 March 2007, no. 18,315, p. 13).

Isolated looting was reported during the red alert phase of the cyclone (JIR, 10 March 2007, no. 18,324, p. 9). As of 4 March, 33,500 households were still without water (JIR, 4 March 2007, no. 18,318, p. 11), and continued high stream levels caused a further drowning on 10 March (Lenormand 2007). By 13 February damage to agriculture was estimated at 12 million euro (Lutton 2007a), causing subsequent inflation of fresh produce prices by 16.2\% (Anon 2007a),
On 15 March a second cyclone, Indlala (with wind-gusts of up to $230 \mathrm{~km} / \mathrm{h}$ ), was reported as approaching NE Madagascar (JIR, 15 March 2007, no. 18,329, p. 6). As of 22 March, $90 \%$ of the Sofia region of Madagascar was reported as flooded with 21 dead and 17,000 buildings damaged, prompting aid from La Réunion (JIR, 22 March 2007, no. 18,336, p. 25). Then, on 31 March, a third cyclone (Jaya) was reported $650 \mathrm{~km}$ north of La Réunion and on course for a second Madagascar landfall (JIR, 31 March 2007, no. 18,345, p. 9). In addition, on 7 May a $3000 \mathrm{~m}^{3}$ rock fall occurred on the main NW-coast road into the island capital, St. Denis (JIR, 8 May 2007, no. 18,382, p. 6). During May, large swells also affected the shores of La Réunion, with waves of up to $7.4 \mathrm{~m}$ causing extensive littoral damage, evacuations and two deaths on La Réunion's south coast (JIR, 8 May 2007 , no. 18,382 , p. $5-15$ ).

\section{Methods}

Between 1 March and 31 May 2007 we collected all copies of the JIR available in PDF format on http://www.clica noo.re/Journal-en-pdf-archives.html (as of 29/05/2018: https://www.clicanoo.re/rechercher?combine=archives). This amounted to a total of 91 issues of the newspaper (note that the issue of 1 May was not published due to a bank-holiday). First, all articles related to hazard were located using the following search strings:

1. "Cyclone" for reporting on cyclone hazard;

2. "Crue" or "innondation" (both meaning flood) for flash flood hazard;

3. "Houle" (swell) and "vague" (wave) for ocean hazard;

4. "Eboulement" (landslide) for rock fall hazard;

5. "Volcan" (volcano) for volcano hazard.

For cyclone and volcano hazard, the search was double checked with a string containing the cyclone name ("Gamède", "Indlala" and "Jaya") or the volcano name ("Piton de la Fournaise"), for the two hazards respectively. If the primary theme of the article was the impact of the on-going event, response to it and/or information to aid in understanding the event, then the article was saved. Selected articles were then assigned one of four hazard theme tags:

1. Cyclone and flash flood (C\&ff);

2. Storm waves and swell (Wav);

3. Land slide and rock fall (RF); and

4. Volcano (Volc).

Cyclone and flash flood were included as one group because the two were difficult to separate, flash floods being a secondary effect of the Cyclone. The volcano category was split between reports of eruptive events at 
non-French volcanoes (Volc-nonF) and local activity at Piton de la Fournaise (Volc-PdlF), where rock falls within the Cratère Dolomieu associated with volcanic events, such as crater collapse and instability, were placed in the Volc-PdlF class rather than the RF class.

\section{Content analysis}

For each article the date, page number, text and image area were recorded. We use area here because this includes the entire content (titles, words and imagery), and is thus the standard measure used in content analysis (Neuendorf 2002). As we argue in Part 2 of this work (Harris and Villeneuve, this volume) minimal use of text may be favored to enhance message delivery, and imagery is a major feature of the tabloid format (Horrie 2003). Thus, using word counts will likely give a significant under-estimate of the news space devoted to the hazard. However, we do consider (and measure) text and image space separately to allow partitioning of the relative importance of text and imagery in delivering the news.

For Piton de la Fournaise-related hazards, each article was also coded according to the dominant volcanic-hazard reported. These were split into five classes:

1. Lava (LAV);

2. Air Fall (AF);

3. Volcano instability and collapse, including pit-crater collapse (IC);

4. Gas and atmospheric effects (GA); or

5. Ocean entry effects (OE).

Eruption (E) was set up as a sixth class into which general information related to the eruptive activity was placed, such as descriptions of seismic events, vent opening or general descriptions of eruptive activity. Within this class a sub-category, "evacuation" was also broken out (E-EVAC).

For each article we extracted all numeric, temporal and locational details contained within the text, recorded all named information sources (including quote providers), and transcribed text recording volcanic hazard descriptions, explanations or warnings. Quote providers were assigned to one of five categories:

1. Information providers $(\mathrm{O})$, including observatory staff, university faculty and members of other research agencies.

2. Decision makers (D), mainly local, regional and national authorities, including the local mayor as well as municipality, prefecture, local and national government spokespeople.

3. Responders $(\mathrm{R})$, including civil protection, police (gendarmerie), fire and medical services (including Red Cross and aid workers), plus military personnel and care workers, as well as forestry, water, electricity and gas services plus community leaders (e.g., school directors, teachers and priests).

4. Business and industry representatives (B\&I) including entrepreneurs and business people (including in agriculture, fishing and tourism industries) impacted by the event.

5. Population $(\mathrm{P})$, a group that was split between residents of the zone at risk (P-R) and visitors $(\mathrm{P}-\mathrm{V})$, i.e., sightseers and tourists.

Article authors, i.e., the journalists responsible for a report, were assigned letters. These were assigned in the order with which their articles appeared. That is, the letter (A) was assigned to the reporter credited with writing the first article in the study period, with subsequent letters being assigned as new reporters contributed. If no author was given, then the article author was assigned "anon."

\section{Tabloid test}

A news value is a theme that determines whether or not an item qualifies for publication in a newspaper (Harcup 2009). Following Harcup (2009), for a tabloid, the news values include:

1. Stories about powerful individuals, organizations or institutions (the power elite);

2. Stories about the famous (celebrity);

3. Stories involving sex, show business, cinema, television, arts, or music;

4. Human interest or animal stories, including an unfolding drama;

5. Opportunities for humorous treatment (entertaining photographs, witty headlines);

6. Cartoons, plus horoscopes, travel, weather forecasts and nature pieces;

7. Stories with an element of surprise;

8. Stories with negative overtones, such as conflict, tragedy, chaos, or suffering (bad news);

9. Stories with positive overtones such as rescues and cures (good news);

10. Stories perceived as sufficiently significant either in terms of numbers of people involved or potential impact (high magnitude news events);

11. Stories about issues, individuals, groups, businesses, industries, places, regions and nations perceived to be relevant to the audience (local news);

12. Stories about subjects already in the news (follow-up);

13. Sports reports;

14. Adverts.

Natural hazards, especially volcanic eruptions, meet many of these tabloid news values, meaning that a tabloid will likely report on the event. Thus, we carried out 
a test to assess whether the JIR was tabloid or not, and-if so-to determine whether there was an influence on the quantity and quality of material appearing.

To do this, we assessed the content of JIR on each Sunday of March 2007. Coding was completed using the page as a unit, where each page was classified based on the dominant news value of the main article on each page. With no exceptions, the theme of the main piece reflected that of all reports appearing on the whole page. To simplify the results, coded classes were then grouped into six main categories:

1. News: Any article devoted to current local, regional, national, European or world events, whether good or bad or follow-up (i.e., Harcup's values 7, 8, 9, 10, 11 and 12). We split the news out into four sub-categories: (i) bad news (murders, car crashes, violence, the macabre, etc.), (ii) local news, (iii) follow-up, and (iv) weather reports/forecasts.

2. Power elite: Reporting of any political event (past, future or present) or people in political, governmental or business positions. Included in this category were economic and business reports (i.e., Harcup's value 1).

3. Sports: Any report of a sporting event or a famous sports person (i.e., Harcup's value 13).

4. Popular: This included mostly 'human interest' stories covering past murders, general articles about increasing drug usage, crime, the environment, popular science and 'feel-good' stories about people and small businesses, as well as travel and horoscopes (i.e., Harcup's values 4, 5 and 6).

5. Entertainment: This included reports on the media (newspapers, Facebook, etc.), film and cinema, the arts, literature, TV and personalities (i.e., Harcup's value 3 ), as well as the famous and celebrities (i.e., Harcup's value 2).

6. Adverts (i.e., Harcup's value 14).

Following Conboy (2004), a domination of categories three through six, at the expense of categories one and two, will define the newspaper as a tabloid. Following Harcup (2009) and Horrie (2003) a dominance of local interest, local news, bad news, follow-up pieces and pictorial information will also define the newspaper as a tabloid. To allow comparison we also completed an analysis of seven other French Sunday newspapers published during March 2014: Ouest France, La Montagne, Le Figaro, Le Monde, Aujourd'hui, Libération and Le Journal du Dimanche.

\section{Results}

\section{Content analysis}

A total of 274 non-volcanic hazard-related articles and 153 Piton de la Fournaise-related articles were identified, with at least one of the four hazard classes (cyclones and flash floods, waves, rock falls and landslides, and volcanic) being reported during all study days except five (7, 23, 29 and 31 May, plus 25 March). Of the 90 issues of JIR studied published over the three-month long study period, hazard-related articles occupied a total paper area of $21.94 \mathrm{~m}^{2}$. This means that around $5 \%$ of the total area of paper printed during March, April and May 2007 was related to natural hazards, representing a hazard-related news-feed of $0.24 \mathrm{~m}^{2}$ of information per day. Of the four hazard classes, cyclones and flash floods were the most reported events, then volcanic events, waves and rock falls (Fig. 2). Non-local hazards (i.e., hazards occurring beyond La Réunion) were only reported on six days across nine reports (Fig. 3). These were all volcanic events and accounted for just $0.6 \%$ of the hazard reporting by area.

March 2007 was dominated by reporting of cyclone damage (Fig. 3a). This was mainly the result of the severe and widespread damage caused by Gamède, where notices of clean-up and repair continued through the end of May. In-spite of Gamède dominating reporting during March, volcanic-hazard managed to take $41 \%$ of the page space devoted to hazard reporting in the last five days of the month (Fig. 3a). During April, volcanic-hazard accounted for more than $80 \%$ of page space devoted to hazard reporting on all but four days (Fig. 3b). Reporting of the April 2007eruption dominated hazard reporting until 8 May (Fig. 3c), when the rock fall that blocked the road into St. Denis took over as the primary focus. Then, between 13 and 21 May, hazard reporting became dominated by the big swells. All the same, the final hazard-related report of the month was devoted to rock fall activity in the Cratère Dolomieu (Fig. 3c).

\section{Piton de la Fournaise 04/07: Quantity of information}

Of the $92,350 \mathrm{~cm}^{2}$ of reporting that was set aside to Piton de la Fournaise during March, April and May 2007, 85\% was concentrated in the month of April. Of the remainder, 3\% occurred in March and 12\% occurred in the post-eruption month (May). If we examine the daily distribution of eruption reporting, we see a first peak on 1 April (Fig. 4a), the day after the short first phase of the eruption on the SE flank of the Cratère Dolomieu. Reporting then remained above $2000 \mathrm{~cm}^{2}$ per day between 3 and 13 April. Thereafter, the average declined from $4962 \mathrm{~cm}^{2}$ per day (3-13 April) to $977 \mathrm{~cm}^{2}$ per day until 3 May when the eruption was declared over. Post-eruption reporting declined further to $409 \mathrm{~cm}^{2}$ per day until 20 May. Thereafter volcano-related reporting became sporadic (Fig. 4a).

The page position assigned to the eruption showed a similar trend, with the eruption maintaining front-page status until 13 April, when eruption reports were 


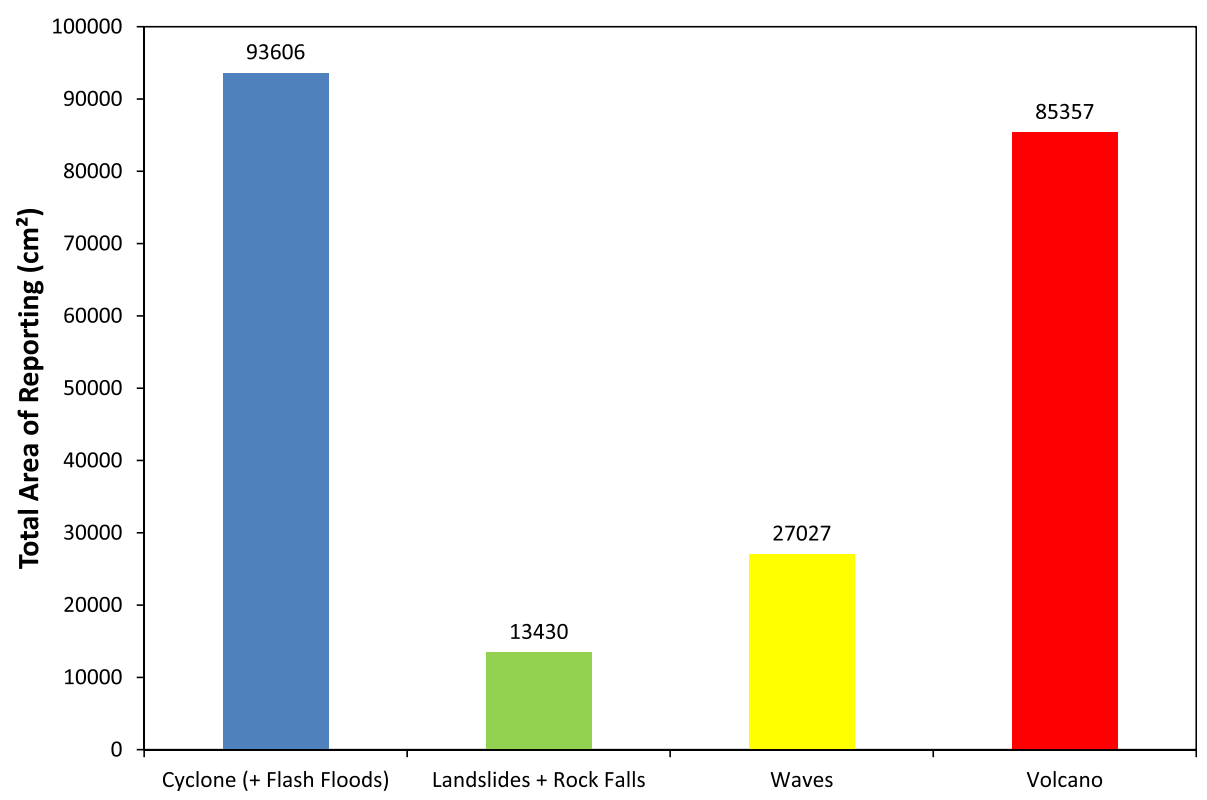

Fig. 2 Total amount (in $\mathrm{cm}^{2}$ ) of hazard information, broken out by hazard type, published in JIR between 1 March and 31 May, 2007

demoted to a position deeper in the newspaper (Fig. 4b). In Fig. 4c, we plot what we define as news "intensity", this being the magnitude of coverage (the total area of reporting on any one day) divided by the highest page number on which reporting occurred. We find that the trend in reporting intensity followed that of the actual eruption intensity (Fig. 4c), as expressed by the time-averaged discharge rate of lava erupted as given by Coppola et al. (2009). Two peaks in news intensity on 22 and 27 April were due to a special section in the Sunday magazine section of the newspaper devoted to the Cratère Dolomieu and its collapse history and a two-page photomontage of lava photographs on the two dates, respectively. In May, the volcano found front-page status on four of the 15 reporting days, but was generally reported on pages 3 to 8 , and as low as on page 17 .

\section{Piton de la Fournaise 04/07: Type of volcano-related topics reported}

We can identify seven volcano-related topics deemed newsworthy by JIR. These are, in order of importance by report area (Fig. 5a):

1. Lava flow inundation;

2. Summit collapse and rock falls;

3. General eruption issues;

4. Evacuation;

5. Gas and air-quality issues;

6. Ocean water quality and ocean entry hazard; and

7. Air-fall hazard
If we consider text reporting only, lava slips to the third-most newsworthy item, with general eruption issues moving to first place and summit collapse to second place; all other impacts maintaining the same rank (Fig. 5b). The type of volcano-related topic reported also changed with time and, generally, as activity evolved (Fig. 6):

- Lava reporting dominated the beginning (3-5 April) and end (22-29 April) of the eruption, even though lava flows were active during the entire eruption (Staudacher et al. 2009);

- Airfall was newsworthy for three days, between 4 and 7 April, when fountains were highest (2-6 April)-so that the heaviest and most widespread air fall occurred to the SE of the vent during this time (Staudacher et al. 2009);

- Gas was only newsworthy between 4 and 8 April, whereas peak $\mathrm{SO}_{2}$ emissions were recorded between 6 and 14 April (Tulet and Villeneuve 2011);

- Evacuation became an issue between 5 and 12 April, correlating with the evacuation itself;

- Collapse events dominated reporting on seven days during the middle of the eruption (7-22 April), although the major collapse occurred on 5-6 April and was followed only by "only minor readjustments" (Peltier et al. 2009);

- Ocean entry issues were only addressed on 9-12 April, as well as on 15 April; with bench collapse dominating reporting on a single day: that of 28 April. This was despite the fact that lava began to enter the ocean on the first day of the eruption, 

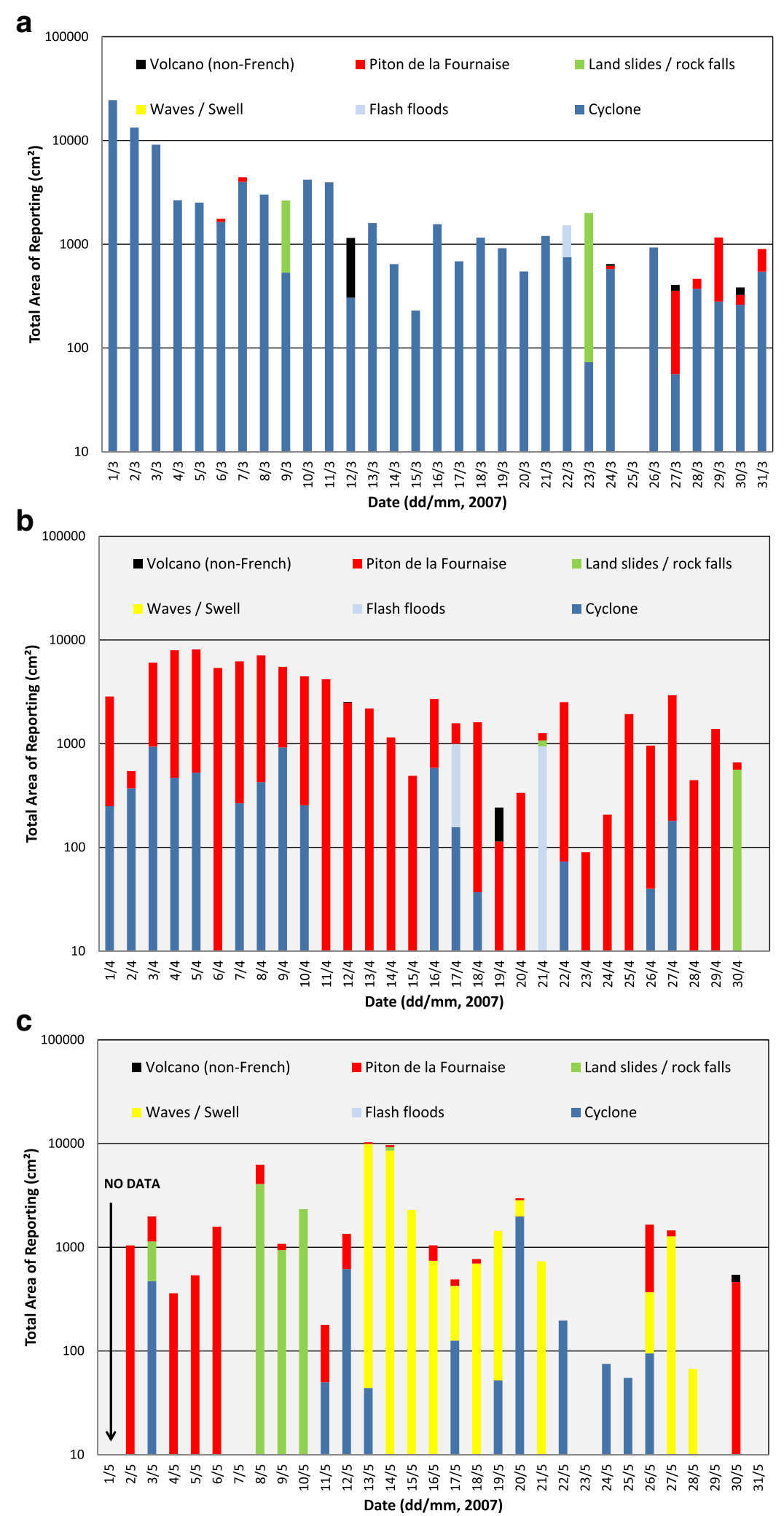

Fig. 3 Daily amount (in $\mathrm{cm}^{2}$ ) of hazard information, broken out by hazard type, published in JIR during (a) March, (b) April, and (c) May, 2007 


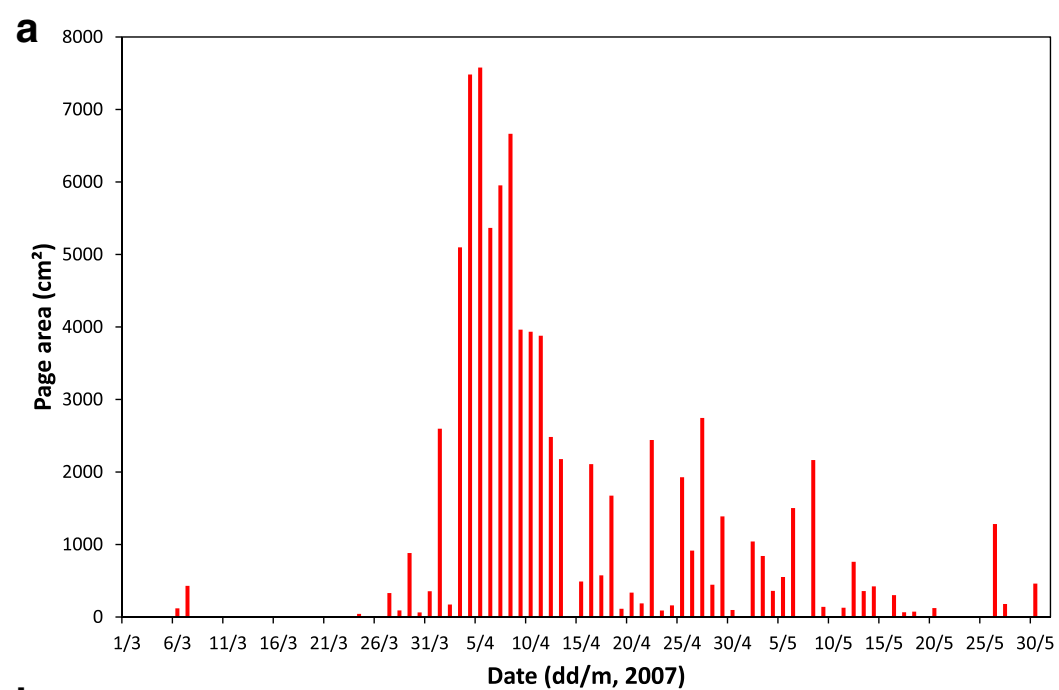

b

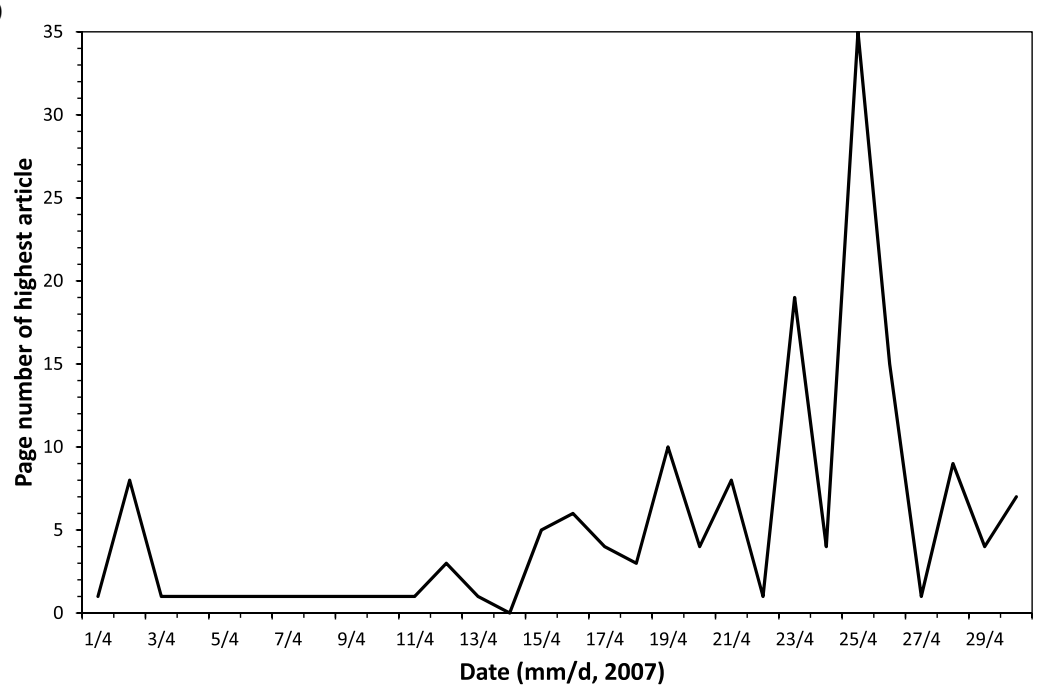

C

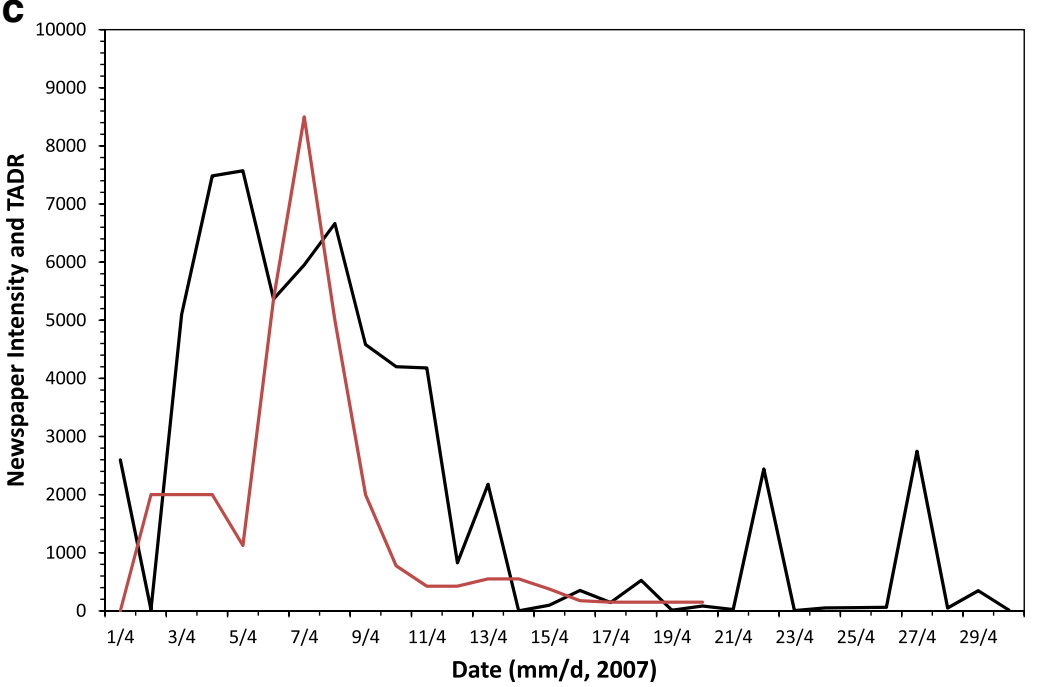

Fig. 4 a Daily amount (in $\mathrm{cm}^{2}$ ) of information devoted to Piton de la Fournaise, as published in JIR between 1 March and 31 May, 2007. b Highest page number in which a Piton de la Fournaise articles appeared in JIR during April 2007. c News intensity and Time-Averaged Discharge Rate (TADR), TADR are from Coppola et al. (2009) 


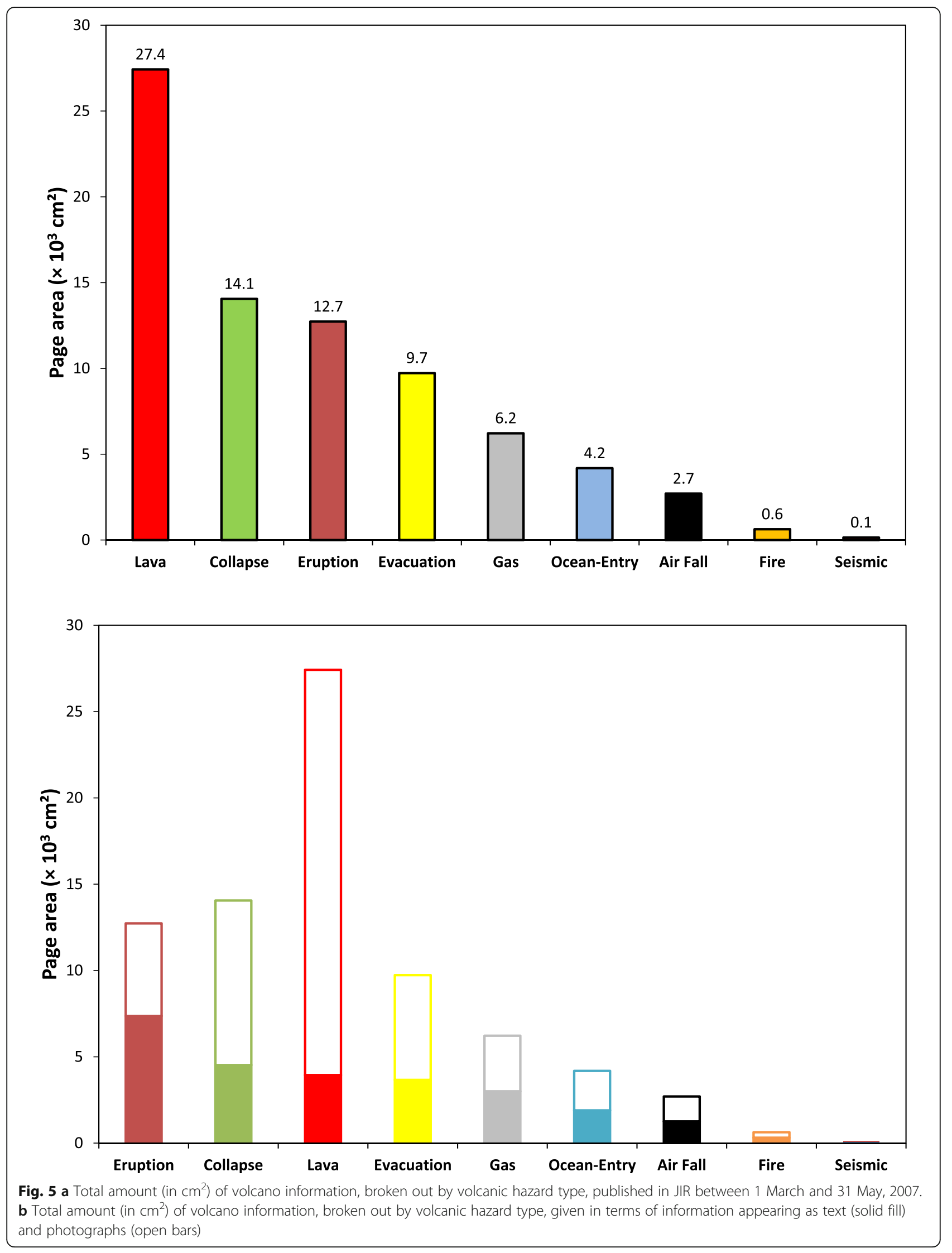




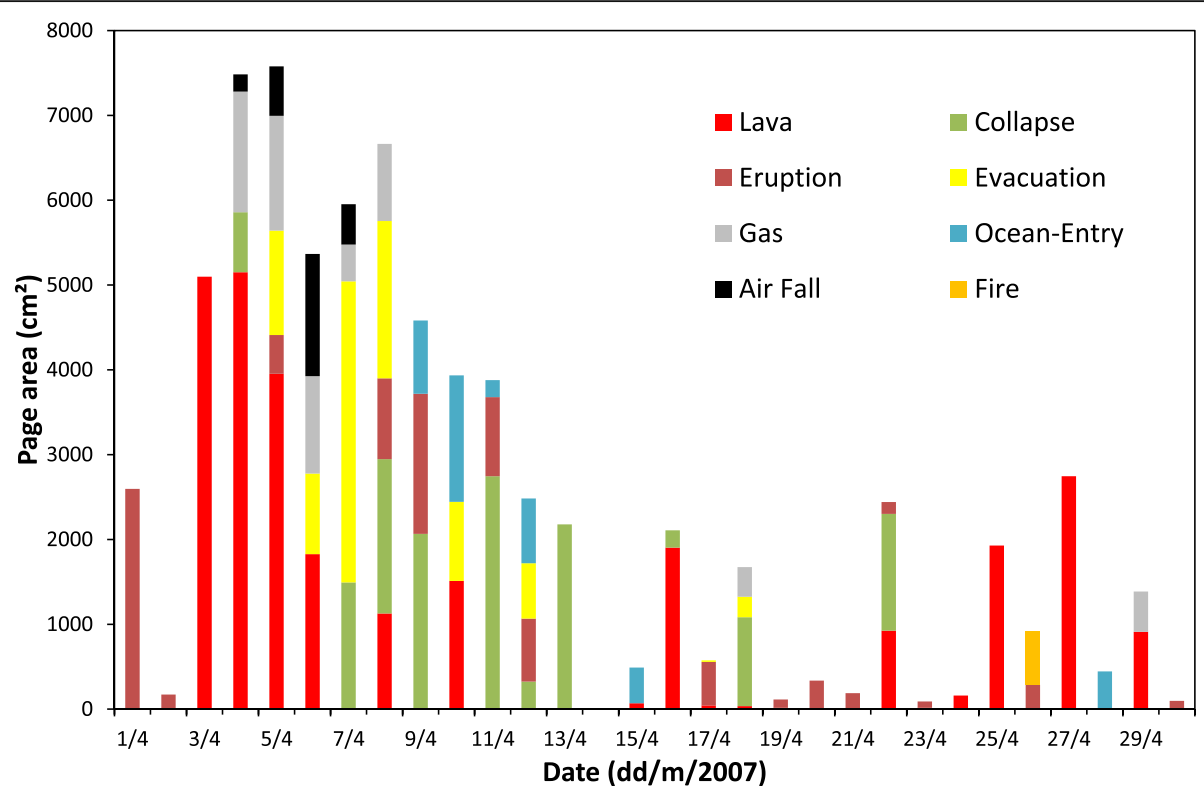

Fig. 6 Daily amount (in $\mathrm{cm}^{2}$ ) of volcano information, broken out by volcanic hazard type, published in JIR during April, 2007

i.e., at 17:25 on 2 April (Staudacher et al. 2009), to build-by the end of the eruption-a near-shore submarine volume of $90 \times 10^{6} \mathrm{~m}^{3}$ (Bachèlery et al. 2010).

Minor topics covered were vegetation fires (due to ignition by lava), seismic hazard and visitor accidents. Fires were only reported at the very end of the eruption, when damp-down operations were reported as necessary for vegetation on the Rampart near the Le Tremblet access road (RN2, Fig. 1) on 26 April (JIR, 26 April 2007, no. 18,371 , p. 15). Another vegetation fire ignited by the heat of the lava was reported near one of the sightseeing access paths on 13 May (JIR, 13 May 2007, no. 18,387, p. 5). However, fires were of minor concern, occupying just $0.97 \%$ of the space devoted to reporting of volcanic hazard. Space set aside to seismic hazard was lower still (0.22\%), being limited to one report on 27 March when a magnitude two volcano-related earthquake was felt in Saint-Denis (JIR, 27 March 2007, no. 18,341, p. 8). As we describe later, the only fatality associated with the eruption was the result of a tourist accident, which occurred six days after the eruption ended (JIR, 9 May 2007 , no. 18,383 , p. 7 ).

\section{The tabloid test}

Our assessment of the content of the March 2007 Sunday editions of JIR reveals that these contain 23\% news, $43 \%$ of which is bad news, $22 \%$ of which is local news, and $22 \%$ of which is follow-up material. Entertainment makes up almost $50 \%$ of the page space and sports $28 \%$ (Fig. 7). By the definition of Harcup (2009), JIR is thus a tabloid, as it is dominated by entertainment and sports, with news reporting focusing on bad and local news, as well as follow-up. Indeed, all of the French press sources considered here are tabloids in terms of content, with the possible exception Ouest France. That is, there is a dominance of news about celebrities, entertainment, lifestyle features, personal issues and television culture. Because we only considered the first section of each newspaper, in some cases the sports category had a zero contribution. Ouest France, for example, publishes its sports coverage as a separate supplement on Sunday. However, for Le Monde, Sunday sports' reporting was genuinely zero. In effect, very little current news is

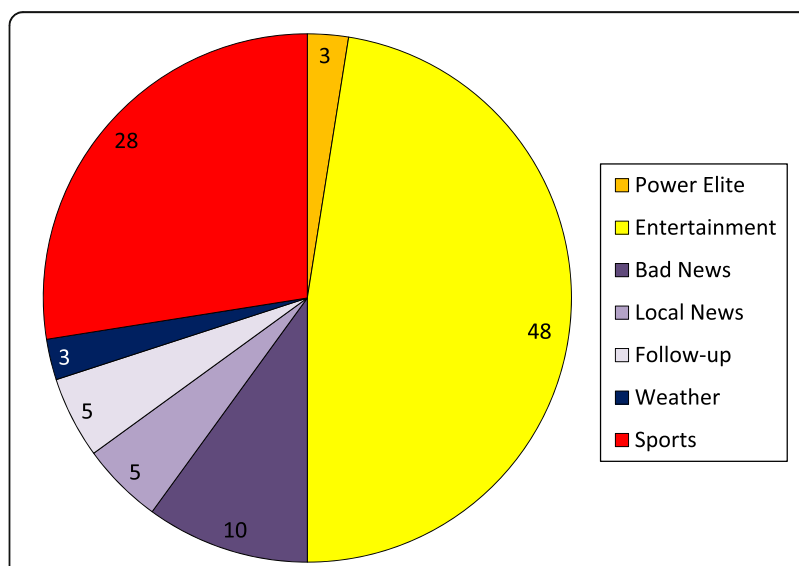

Fig. 7 Percent of JIR taken up by the six news value groups collated from Harcup (2009), with percentage values given as numbers (the news group is divided into its four tabloid sub-classes: bad, local, follow-up and weather) 
actually reported (Fig. 8). In terms of news, JIR is the 3rd best source of the eight newspapers analyzed, it is the lowest ranked in terms of political content, but is highly ranked in terms of inclusion of popular and entertainment items (Fig. 8a). With the exception of Ouest France, for which $63 \%$ of the newspaper was devoted to news, typically less than $20 \%$ of page space is devoted to current news (Fig. 8a). On average space in any newspaper analyzed is devoted evenly to news $(18 \%)$, politics $(15 \%)$, sports $(16 \%)$, and popular issues $(17 \%)$. The greatest amount of space (29\%) is devoted to entertainment
(Fig. 8b). The dominance of tabloid news values is exaggerated if the Ouest France statistics are removed. Now the average for news reporting falls to between 4 and $11 \%$ depending on the newspaper considered, with $53 \%$ of the newspaper space being devoted to popular pieces, entertainment and adverts.

\section{Hazard reporting and communication: Timeline}

In completing the event chronology that follows, we use quoted material to support the arguments that precede and follow them. The event-frame, and potential impact

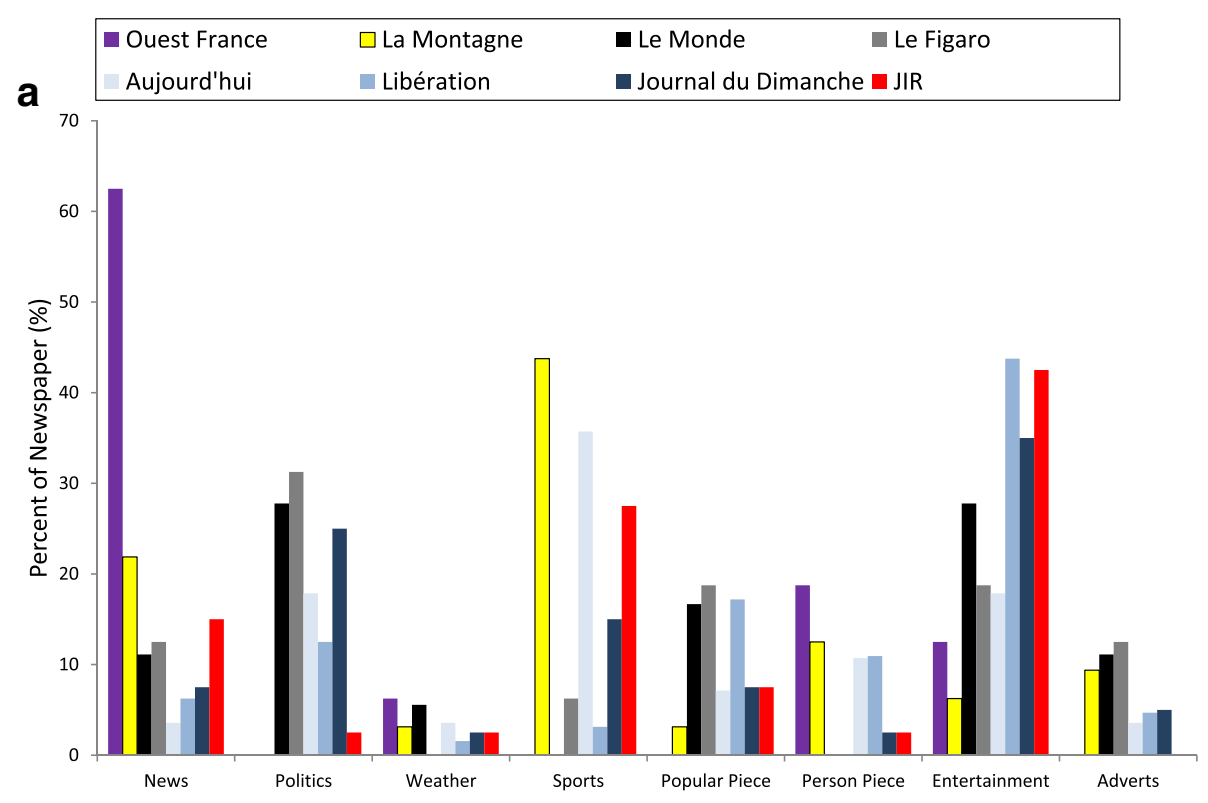

b

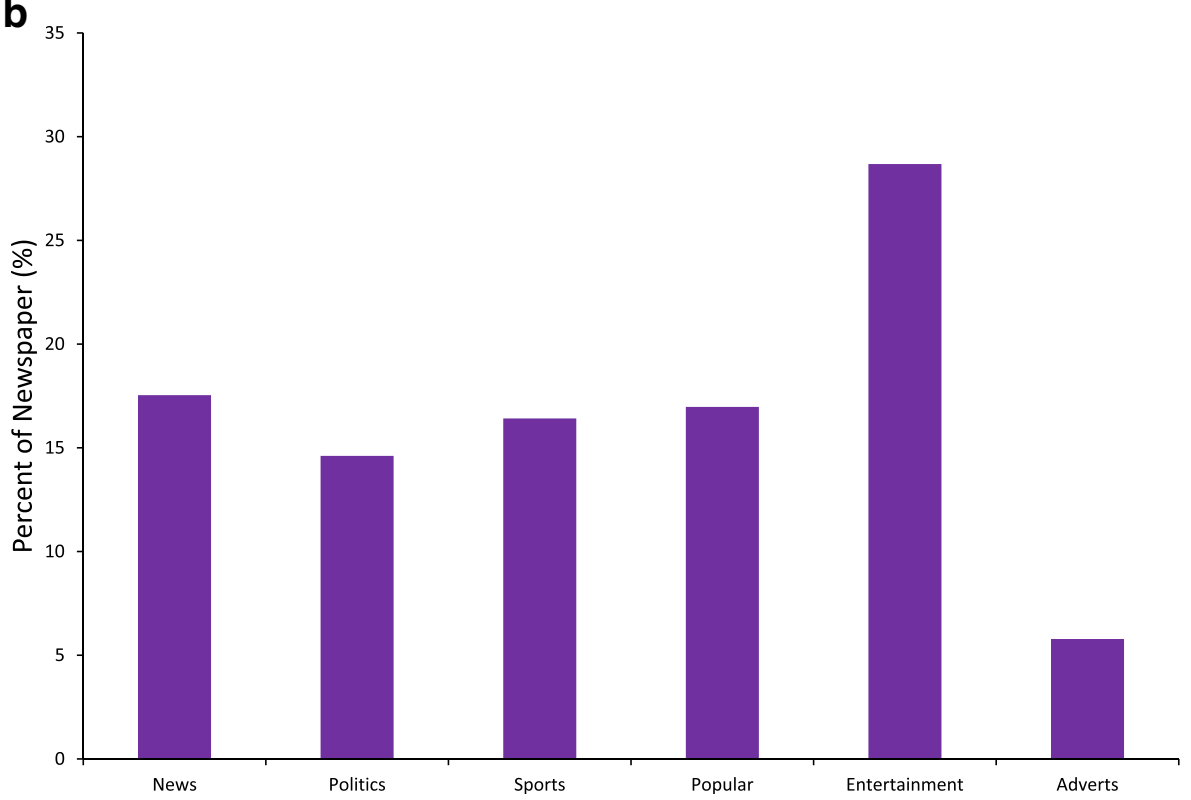

Fig. 8 a Categories of news appearing in eight French newspapers by percent of each newspaper dedicated to each theme; (b) Categories of news appearing in all eight French newspapers by total percent of all newspapers dedicated to each theme 
on readership perception, is examined, tested and analyzed in the second part of this work (Harris and Villeneuve, this volume). Here, our content analysis results are used to (i) build the timeline, and (ii) demonstrate the quality of information available.

\section{Precursory reporting (March 2007)}

Reports relating to volcanic activity appeared on eight days during March 2007, including four consecutive days prior to the April 2007 eruption. Reporting was factual, and not interpretive or predictive, giving the number of seismic events per day with a comment as to whether these were increasing, decreasing or stable compared with previous days. The first three reports (on 6 and 7 March) covered re-opening of the volcano following access closure during the 18 February eruption (Anon 2007b; Martel-Asselin 2007a), as well as an unsuccessful attempt to overturn a law, put in place following a fatality in 2003, requiring volcano lock down at night and during eruptions (Martel-Asselin 2007b). However, the 6 March report added the caution, attributed to OVPF and accurately iterating their bulletin, that there was (Martel-Asselin 2007a):

"always the possibility of a new eruption due to the persistent increase in deformation recorded at the summit."

The next report, on 24 March, indicated (again citing OVPF) that the number of seismic events had increased, and that there was a moderate chance of a new eruption in the short term; although under the misleading title "eruption announced" (Anon 2007c). On 27 March, supported by graphics showing the number of seismic events per day since 1 January 2007, further increases in seismicity were reported, so that the first level of alert ("an eruption is probable in the days or weeks to come") was reported as being put in place by the prefecture (Martel-Asselin 2007c). Included in this report was the advice that, if encountering a lava flow, the individual should leave laterally and not run. Over the next two days (28 and 29 March) the alert and response system, as well as the protocols to be applied during each alert phase, was further clarified (Table 1). The following day (30 March) intensification in seismic energy was noted, with an OVPF-sourced (and again accurately reproduced) statement reporting (Anon 2007d),

"we are still at a 'volcano watch' level, an eruption is expected in the short term."

The onset of eruptive activity was announced on page 1 of the 31 March edition of JIR with a text box in the upper-left corner of the front page reading "Piton de la Fournaise in eruption since yesterday evening." Following a seismic crisis that began at 20:24 on 30 March, the eruption broke out at 23:00 when a seismic signal consistent with lava flow was reported by OVPF; with the eruption location being correctly given as in the south of 'L'Enclos' (Fig. 1), at an

Table 1 Alert level usage, descriptions and response advice given in JIR on 28 and 29 March 2007

\begin{tabular}{ll}
\hline Alert Level & Advice \\
\hline Vigilance Volcanique & "the possibility of an eruption at any time, in the days or weeks come" \\
(Volcano Watch) & (Martel-Asselin 2007d) \\
"pre-alert" & "This phase essentially aims to alert the state services to the case of an imminent eruption (Gendarmerie \\
& Service, County Fire and Relief, NFB, DDE, etc.). Consequently, there is no need to be alarmed and \\
& stockpile(!); Although one must not ignore the risk of activity outside of 'enclos'. The response plan \\
& provides for the evacuation of inhabited areas if necessary (examples: Sainte-Rose 1977, Saint-Philippe \\
& 1986, Bois White 2002). But, be rest assured that, for now, this is not an issue" \\
& (Martel-Asselin 2007e). \\
& "Access to the 'enclos' remains authorized during the "pre-alert", thus this phase relates essentially to \\
& hikers, who are encouraged to keep their eyes open and to remain alert to any unexpected event" \\
& (Martel-Asselin 2007e).
\end{tabular}

Alert 1

Alert 2

In case of a sudden eruption before evacuation can occur
"In the case of a seismic crisis and the ascent of magma towards the surface, alert 1 for an imminent eruption is issued and the 'enclos' is evacuated" (Martel-Asselin 2007d).

"Alert 2 corresponds to magma arriving at the surface in a few minutes or within several hours ........ if the crisis aborts, then we return to a the phase of pre-alert" (Martel-Asselin 2007d).

"Keep in mind that eruptions often start at the top of the volcano, inside the Dolomieu crater, and eruptive fissures frequently intersect the path that goes around the crater. In such cases, the only solution is to simply retrace ones steps by carefully following the trail. Do not risk going off of the track; on the slopes, you have every chance of getting lost in the very difficult terrain. If you feel that you are in real trouble, it is better to stay in a high area, and to move away without excessive haste. The edge of eruptive craters are particularly fragile: already destabilized, as demonstrated by the existing cracks, they may collapse (especially) because of the seismicity associated with the eruption" (Martel-Asselin 2007e). 
elevation of $2000 \mathrm{~m}$ in the vicinity of "Chateau Fort" (Martel-Asselin 2007f). Martel-Asselin (2007f) also reported that the police had closed the gate to 'L'Enclos' (i.e., the only easy access route into the caldera from the summit), and gave the web-site address and telephone number of OVPF.

\section{Reporting of the eruption (April 2007)}

The opening phase of the eruption was reported as being over by 09:00 on the following morning (31 March). However, there was the caution that strong seismicity was still on-going, with the report stressing that an OVPF bulletin suggested that a possible reactivation of the eruption could occur at the summit or at lower attitudes (Martel-Asselin 2007g). High levels of seismic activity with magnitudes of up to two at depths of 1-2 km below sea level on the E and ESE flank were reported the next day (1 April). These details appeared with the OVPF-credited statement that (Anon 2007d):

"A recommencement of activity in the hours or days to come cannot be excluded."

Then, on 2 April, the second phase of the eruption was reported to have begun at an elevation of $600 \mathrm{~m}$ in Le Grand Brûlé close to the south wall of 'L'Enclos' (Fig. 1) at around 10:00. Flows were reported to have formed two branches, the first of which crossed the RN2 at 15:15 to enter the ocean at 21:45; the second crossing the road at 17:20, with both flows burning the heavy vegetation through which they were moving (Dupuis 2007b). This new development was marked by a full front-page feature picturing lava advance across RN2. Meanwhile, on 3 April, continued and strong (up to magnitude two and three) seismic activity beneath the Cratère Dolomieu was reported to be causing concern of a potential summit collapse (Martel-Asselin 2007h). Closure of the RN2 between Piton-Sainte-Rose and towns to the south of the L'Enclos (Fig. 1) was reported as causing difficulties for those employed in the former towns and resident in the latter (P.M. 2007a). The problems, and a hint at the onset of resilience, were summed up by the principal of the Collège Therésien Cadet in Piton Sainte-Rose who was quoted as saying (P.M. 2007a):

"Despite between 2 hours and 2 hours 30 minutes of additional road travel, our twelve teachers, our secretary, and our librarian who live on the other side (of 'L'Enclos') took up their service normally. The problem is for those who finish work at 16:30 and then resume again early the next day, they prefer to stay in Sainte-Rose, often with another teacher as a host. Solidarity takes over."
By 5 April the two lava flows (Fig. 1) had become well-established, the northern branch being named the Sainte-Rose-side flow (La coulée côté Sainte-Rose) and the southern branch being labeled the Saint-Philippe-side flow (La coulée côté Saint-Philippe) by JIR on 6 April.

\section{Gas and air-fall (4-6 April 2007)}

Although the front page of JIR and the first full page of internal reporting was devoted to the lava activity and visitors viewing the flows and ocean entry (Anon 2007e; Dupuis 2007c), by 4 April gas emission had become a serious problem. In Saint Joseph, gas impacted three schools causing respiratory problems for around 50 students, of which 14 were taken to hospital (P.M. 2007a). The following day a four-year-old child was reported as having been admitted to Saint-Paul hospital having suffered difficulties following "inhalation of far too much $\mathrm{SO}_{2}$ " (G.L. 2007). On 4 April populations to the south of the eruptive fissure were also reported as beginning to suffer from the effects of air fall (P.M. 2007a). Initially, on 4 April, this involved large quantities of Pele's Hair, locally known as "zépines de Madame Desbassayns" (Martel-Asselin 2007i), but this was reported to have turned to ash around 18:00 on 5 April (Martel-Asselin 2007j).

A lack of information regarding gas and ash hazard was rectified on 5 April in two articles describing the effects, and correct response, to gas and air fall (Table 2). Sulfur dioxide levels were reported as elevated island-wide, but were particularly high in towns proximal to the source. A sulfur dioxide load of 300 micrograms per cubic meter of air was reported at 11:45 in Saint-Louis on 5 April (T.L, $2007 \mathrm{a}, \mathrm{b})$, the normal level being reported as $10 \mu \mathrm{g} / \mathrm{m}^{3}$ (Amiotte 2007a), with the alert level being cited as $500 \mu \mathrm{g} / \mathrm{m}^{3}$ (Amiotte 2007b). This caused the gas-response recommendations of 5 April to be repeated on 6 April (T.L, 2007a, b), although with some inconsistencies in threshold values. For example, on 7 April Dupuis (2007d) wrote,

\footnotetext{
"The levels of sulfur dioxide are well below the threshold of 300 micrograms per $\mathrm{m}^{3}$. The danger threshold is 800 microgram per $\mathrm{m}^{3}$. Drinking water from catchment sources is also being monitored to detect the possible presence of Pele's hair. No pollution of this nature has been detected."
}

On 7 April the first agricultural effects of air fall began to be reported (T.L. 2007a), with the problem of Pele's hair covering pasture prompting the Chamber of Agriculture to issue advice to famers whose operations had been affected (Table 2). On 8 April a resident of Le Tremblet also gave one of the first indications of vegetation damage by acid rain, stating that (Lutton 2007b): 
Table 2 Gas, ash and ocean entry hazards, and mitigation advice, given in JIR on 5, 7 and 10 April 2007

\begin{tabular}{|c|c|}
\hline Hazard & Recommendations \\
\hline $\begin{array}{l}\text { Gas } \\
\text { (Amiotte, } \\
\text { 2007a) }\end{array}$ & $\begin{array}{l}\text { "Across the whole island, the prefecture recommends, especially for sensitive people (the elderly, children and adults with } \\
\text { respiratory diseases or chronic cardiovascular problems) to avoid all intense physical and sporting activities that significantly } \\
\text { increase the volume of air and pollutants inhaled; ensure not to aggravate the effects of this pollution through use of other } \\
\text { irritants such use solvents or paints without proper protection, or tobacco smoke. Persons under preventive or curative } \\
\text { treatment for respiratory problems are recommended to strictly follow their treatment or to seek the advice of a doctor." }\end{array}$ \\
\hline $\begin{array}{l}\text { Ash (Pele's hair) } \\
\text { (Martel-Asselin } \\
\text { 2007i) }\end{array}$ & $\begin{array}{l}\text { "The lava fountains, as visible from the RN 2, project myriads of droplets that become stretched during movement through the } \\
\text { air in the form of long strands (from a few to about fifteen centimeters in length) that can be driven by the wind over distances } \\
\text { that can reach several tens of kilometers .......... The Chamber of Agriculture encourages farmers to return their animals to } \\
\text { cover wherever possible as ingestion or inhalation may cause 'irritation and ulceration as respiratory and intestinal problems' ... } \\
\ldots \ldots \text {... farmers should be wary of reserves of water and fresh feed left in the open-air, and consequently to favor (use of) } \\
\text { conserved forage. Then (the farmer needs to) wait for the rains to flush the soils and pastures. Human consumption of vegetables } \\
\text { and fruit should be monitored, and clean the fruit (prior to eating) if necessary." }\end{array}$ \\
\hline $\begin{array}{l}\text { Acid rain } \\
\text { (Amiotte, 2007c) }\end{array}$ & $\begin{array}{l}\text { "The dangers are mainly cardiovascular and are of particular concern for asthmatics. However, there may also be skin irritation } \\
\text { related to hydrochloric acid and sulfuric acid. Both gases can cause minor erythema (redness of the skin) which are like minor } \\
\text { burns. If necessary treat such a condition as a burn with Biafine. Exposure may also cause conjunctivitis. If you experience any } \\
\text { of these symptoms, it is best to consult a doctor." }\end{array}$ \\
\hline $\begin{array}{l}\text { Agricultural } \\
\text { impacts } \\
\text { (T.L. 2007a) }\end{array}$ & $\begin{array}{l}\text { "The ingestion of Pele's hair by cows and goats can provoke irritation, which in the worst cases can lead to death } \ldots \ldots \ldots \ldots \\
\text { (thus) } \ldots \ldots \ldots \text { keep cattle in barns and feed them hay, dry straw and animal food." }\end{array}$ \\
\hline $\begin{array}{l}\text { Ocean Entry } \\
\text { (Frasson-Botton, } \\
\text { 2007) }\end{array}$ & $\begin{array}{l}\text { There is a very hot surface layer of water. Certain boats and jet-skis are approaching dangerously close to the coast, such a } \\
\text { location is not essential in order to observe the activity. Above all there are restrictions enforced by the Prefecture and } \\
\text { Municipality. In comparison to 2004, the arrival of lava at the sea is more dangerous. The layer of burning water extends down } \\
\text { to } 300 \text { or } 400 \mathrm{~m} \text { in depth. }\end{array}$ \\
\hline
\end{tabular}

"The iron roof of my house is rusty. Acid rain and hot ash have damaged the roof. My garden is completely burned. I don't have plants anymore".

Damage to sugar cane crops due to acid rain was reported as far away as Mauritius, around $220 \mathrm{~km}$ to the NNE (Anon 2007f).

\section{Evacuation of Le Tremblet (5-6 April 2007)}

By 5 April, it was clear that evacuation of Le Tremblet, just to the south of 'L'Enclos' (Fig. 1) may be necessary. It was stressed that the problem for Le Tremblet was not a "threat", but instead a "risk", with the reason for that risk being clearly stated as frequent and strong (magnitude two and three) earthquakes at shallow levels ( 0 to $1 \mathrm{~km}$ asl) in the southern sector of the volcano (Martel-Asselin 2007j)-leading to concern of propagation of the eruptive fissure to a location just above the village. Hence, Martel-Asselin (2007k) reminded the readers that,

"although it is impossible to predict at present if an eruption can occur in 'L'Enclos' or outside of 'L'Enclos' ... ... ... opening of a new eruptive fissure at lower altitudes than the current $(600 \mathrm{~m})$ fissure still remains within the realm of probability."

Martel-Asselin (2007k) further supported the potential risk of lava entering Le Tremblet by writing:
"If a fissure opens at $300 \mathrm{~m}$, for example, the lava might arrive in Le Tremblet (at $150 \mathrm{~m}$ in altitude) probably a lot faster than we think."

The main report of 5 April thus focused on the potential evacuation of Le Tremblet. Reporting revealed a clear response plan, with the prefecture outlining that it would take between two and three hours to evacuate the population of 350-400, where the evacuation would be managed on the ground by the police and fire departments-with access roads already having been cleared and closed in order to facilitate evacuation (Leyral 2007a). The prefecture, through the JIR, stressed that evacuees should just prepare personal papers and essential items, and that seven vehicles with a total capacity of 32 had been made available. The facilities to be used as evacuation centers (sports halls, community halls, etc.) were listed. The same report also indicated that the population was prepared and ready, with local residents inviting the reporter to (Leyral 2007a):

"Come and see-my suitcases and all of my personal papers are ready in the trunk of my car"

or

"Our packing is ready, now we will wait".

This state of readiness was iterated, through the JIR, on 6 April with the authorities repeating that the 206 residents of Le Tremblet would be housed in three evacuation centers if need-be, with the fire services 
being reported as making tours to check for those in need of help in case of an evacuation (Leyral 2007b). Then, on 7 April, it was reported that Le Tremblet had been evacuated during the previous day, the report stating that (Leyral et al. 2007a):

"The incessant rain of ash and lapilli, volcanic products of a few millimeters in diameter, projected as far as the sea, pushed the prefecture to advise residents to leave their homes."

Beginning at 15:10 around 100 people were reported as being evacuated by the gendarmerie and fire services, with around 300 residents already having taken the initiative to leave before the official evacuation declaration. However, it was noted that later in the day, although fountains had reached $200 \mathrm{~m}$ (a height which was considered "colossal and very powerful"), no eruption had occurred outside of 'L'Enclos'. This, it was reported, caused the prefecture to rescind the evacuation order (Leyral et al. 2007b). However, most residents stayed away for the next few days as airfall continued to impact the area, and the residents of Le Tremblet were not reported to have "spent a first night at home" until 10 April. By this time many personal cleanup operations were underway, with Lutton (2007c) writing:

"The roofs of houses are covered in sand which must be removed today. 'I cleaned my entire house. Along with the roads and avenues, all of the ground is black', explained one resident."

Water was also reported as still being cut off, and there were continued electricity supply problems. Cleanup operations for Le Tremblet were reported through 15 April, when the Red Cross began to help with water distribution and hands-on aid with house cleaning (Anon 2007g).

\section{Collapse of the Cratère Dolomieu (7 and 12 April 2007)}

On 6 April the Cratère Dolomieu, as had been predicted in the JIR report of Martel-Asselin (2007h) on 3 April, collapsed. The front page of 7 April carried the headline, "The Volcano Collapses". The first report of the collapse in this edition was entitled "an abyss in place of the Dolomieu" and estimated that the new summit pit was $200 \mathrm{~m}$ deep. The same report carried an aviation warning and addressed the aircraft hazard posed by ash plumes from continued collapse events, pointing out that (Martel-Asselin 2007l):

"Such events are subject to international reporting so as not to endanger air traffic, where (aircraft) engines do not like at all to ingest the highly abrasive (volcanic) dust, which can choke the engines. Thus, any air traffic is prohibited in the area. An 'appeal' (warning) was launched yesterday to all aircraft."

A report appearing on page 10 of the 8 April edition of JIR declared that the crater had stabilized with the collapse being "more-or-less finished" (T.L. 2007b), the pit having attained a depth of $300 \mathrm{~m}$ and an area of $1000 \mathrm{~m} \times 700 \mathrm{~m}$ (Anon 2007h). A second collapse was reported as occurring at 15:15 on 12 April, feeding a grey ash plume, which led to a local air traffic warning to be issued by the Toulouse VAAC, and an air fall warning being issued for a zone to the east by Méteo-France (Martel-Asselin $2007 \mathrm{~m}$ ). The event was exceedingly well documented in a two page report of Martel-Asselin $(2007 \mathrm{~m})$, a report which was supported by web-cam image time series, aerial photographs and tremor plots from OVPF.

\section{The waning phase (9 April - 1 May 2007)}

On 8 April, the eruption had already been reported as waning, and this was confirmed in the main activity report of Monday 9 April (Martel-Asselin 2007n):

"The threat diminished with the decrease in tremor: the eruption that began last Monday has stabilized at $500 \mathrm{~m}$ above sea level, and the risk of activity beyond 'L'Enclos' now seems less of a concern. The show has also decreased significantly since Saturday."

It was at this point that the effects of the ocean entry of lava on marine life began to be reported, with dead fish being reported as floating up from depths of 70 to $200 \mathrm{~m}$, even as deep as $500 \mathrm{~m}$ (Frasson-Botton 2007), where dead fish exhibited "swollen bladders, extended stomachs and inflated eyes" (Lauret 2007). The following day (10 April), while a "hot water" warning was posted in the newspaper for boats and jet-skis approaching the shore (Table 2), the main eruption report suggested that the on-shore lava channels were beginning to roof over (Anon 2007i).

The eruption was reported as having stopped at 14:00 on 10 April, and the lava fountains were reported as having waned a little earlier at 12:30 (Martel-Asselin 2007o). However, new lava flows were viewed a few hours later. These were reported as reaching the ocean once more during the evening (Martel-Asselin 2007p). Ocean-entry flow was reported as continuing through 14 April (Anon 2007j), and two tube-fed ocean entries were reported as active on 15 April (Martel-Asselin 2007q). Thereafter the amount of reporting diminished, with the eruption of Nevado del Huila in Colombia taking up more newspaper space than the on-going eruption of Piton de la Fournaise on 19 April (Fig. 3b). On 24 April, 
quoting OVPF, it was reported-on page 4-that (Leyral and Martel-Asselin 2007):

"Numerous lava flows remain visible in the GrandBrûlé, (and) lava flows between the cone at $650 \mathrm{~m}$ and around 250 to $300 \mathrm{~m}$ flow in a lava tube, whose roof is broken by lava overflow to form a hornito."

\section{The end of the eruption (1-3 may 2007)}

No newspaper was published on 1 May, but on Wednesday 2 May a page 6 article, entitled "A new eruption possible", led with:

"The relief expressed by residents of Le Tremblet on Monday from the announcement that lava flows were drying up and of the virtual disappearance of eruptive tremor could be premature. Seismicity remains high and, according to the Volcano Observatory, a continuation of the 2 April eruption cannot be excluded."

The observatory was quoted as adding that high levels of vigilance should be maintained (Martel-Asselin 2007r). The official declaration of end of the eruption was announced the following day (3 May) in an article containing a statement accredited to OVPF, that (Martel-Asselin 2007s):

"'Due to the thickness of the lava flows near Le Tremblet rampart, which is of the order of 30 to 40 $\mathrm{m}$, there clearly exists a reservoir of fluid lava beneath the surface. This reservoir flows passively to feed lava to the sea through tubes and forms a plume.

Degassing at the cone is secondary degassing due to the high temperatures that remain beneath the cone. The absence of tremor signifies that the eruption is over, reaffirmed the observatory, so that deep supply cannot exist any longer."

Le Tremblet was also reported as accessible to the public again, with four new viewing points being announced on 5 May (Martel-Asselin 2007t), as marked on Fig. 1.

\section{Post-eruption reporting (May 2007)}

In the days immediately after the eruption, news was dominated by information regarding access for sightseers and visitor impressions, although access to the flow field itself remained closed to visitors during May. Between 4 and 8 May eight articles were published, all focusing on the access theme. Visitors were "shocked" by the loss of the road, as well as the damage to vegetation. It was during this phase that the only fatality related to the eruption occurred, when a man returning from the
Le Tremblet viewing point (Fig. 1) suffered a fatal heart attack near Le Tremblet church (Anon 2007k). This is what Blong (1984) would class as "avoidable" loss because it is a loss resulting from the victim approaching the hazard, and/or the hazard attracting visitors whose lack of preparedness for, for example, a long hike in hot and humid conditions or poor decision-making contributes to the loss (Harris 2015c). It is not an uncommon problem around sites of active lava flow (Heggie and Heggie 2004; Heggie 2005). Fatalities among the bird community were also reported, where burnt sea birds were found on the cooling lava flows. After 9 May, reporting regarding the eruption and access diminished in terms of quantity and frequency (Fig. 4a). Reporting continued, though, due to ongoing rock fall activity in the Cratère Dolomieu, which was ascribed to system "readjustment" (Anon 2007l).

Only three articles of the 30 eruption-related reports that appeared during May 2007 referred to post-eruption response. One dealt with the re-laying of the RN2 road, which was hoped to be completed within two months, the road having been buried over a length of $1.5 \mathrm{~km}$ (Leyral 2007c). The other two reports dealt with community support measures for the population of Le Tremblet. The report of 26 May, although only occupying an area of $358 \mathrm{~cm}^{2}$ and appearing on page 24, ten pages after the road report of Leyral (2007d), vividly illustrated the need for mental health intervention. One resident was reported as saying (Anon 2007m):

"There are people who have lost everything here, if they do not have moral support-then they really have nothing."

\section{A priest added:}

"These people need human relations to feel loved."

The re-opening of the road was reported to likely cost 1 million euro (Leyral 2007d), but 135 euro would allow guided access into the lava flow field; an experience that was considered by most visitors as being a "magic" experience (P.M. 2007b). This latter feeling is in complete contrast with the experiences of the impacted population, whose needs and losses were under-reported.

\section{Discussion}

\section{Quantity and frequency of hazard information}

The quantity and frequency of hazard reporting in JIR indicates a strong culture of hazard, both through everyday life experience and exposure to the media, among La Réunion's population. Hazard-related information appeared on the front pages of JIR on 34 out of the 90 
study days, and was reported during 85 days. As a result it is difficult to believe that the population of La Réunion was nothing other than fully aware of, and sensitive to, the natural hazards to which the island was exposed. We may argue that this reflects the tropical-cycline exposed and volcanic environment in which the population lives. However, in the case examined here, it was also promoted by the fact that JIR was a tabloid and that the natural hazards and their impacts fitted well with the news values of the tabloid. As a result, there was extensive coverage. Based on databases we have for newspaper reporting of natural hazards in the USA, the UK, France and Italy, we argue that extensive coverage of volcanic eruptions, landslides, and storms impacting the readership is indeed a feature of tabloid coverage (e.g., Harris et al. 2012; Harris et al. 2015a, b; Harris and Lanfranco 2017; and other unpublished data). For example, during the air space closure due to the 2010 eruption of Eyjafjallajökull, the British tabloid, The Sun, published by far the greatest amount of information of seven newspapers analyzed, devoting around $30,000 \mathrm{~cm}^{2}$ of newspaper space to the event over eight days, as opposed to just $1000 \mathrm{~cm}^{2}$ of information that appeared in the French broadsheet, Le Monde (Harris et al. 2012). The tabloid thus provides an enormous amount of information to its readership regarding natural hazards.

While Horrie (2003) notes that the tabloid format involves big photograph and human-interest stories, Conboy (2004) remarks that tabloids gravitate towards "sensational" stories. Certainly, the April 2007 eruption suited these tabloid needs. In fact, if we examine the content of the $77,860 \mathrm{~cm}^{2}$ of material dedicated to the eruption between 6 March and 3 May 2007, 67\% of it was in photographic format. Spectacular photographs of the eruption dominated the front pages on nine days of April 2007, and internal sections of the newspaper were frequently devoted to photomontages. This was particularly true for reporting on the lava flow activity, where the spectacular and photogenic nature of active lavaand its fit to the tabloid news values-meant that $86 \%$ of lava reporting was photograph-based (Fig. 5b).

There was also human interest in the gas impacts on schools and the evacuation of Le Tremblet, and the opportunity for sensationalist front page headlines such as "Alerte aux GAZ" (Gas Alert) (JIR, 5 April 2007, no. 18,350, p. 1). The tabloid news values of Harcup (2009) were also met, in that there was:

1. Involvement of the power elite, mainly the state, in the evacuation of Le Tremblet;

2. Human interest (the stories of the residents of Le Tremblet), animal stories (notably the fish killed by the ocean entry) and witty headlines, e.g." "The Volcano's gone mad" (JIR, 4 April 2007, no. 18349, p. 1);
3. Surprise elements such as the effects of gas, the intensity of the eruption and the collapse of the Cratère Dolomieu;

4. Rescues and cures, such as medical interventions and school evacuations due to gas effects and housing of teachers whose route to school had been cut; and

5. The impact was of high magnitude: gas being a problem as far away as Mauritius and being a widespread problem for the southern part of La Réunion; lava also closed the only east-coast road link to cause severe travel problems for residents living on one side of 'L'Enclos' and working on the other; and an entire village was evacuated.

Thus, although we grouped Harcup's (2009) tabloid news values into six parental classes, if we examine the detail of Harcup's (2009) full listing we find that all 14 news values were applied in the case studied here. There was news covering the actions of the power elite and the famous, adverts for museum exhibitions and guided visits, human interest, rescues, follow-up pieces and even effects on sporting events (where many sporting events were reported as cancelled due to the cyclone activity). However, and above all, during a disaster there is plenty of material to fit the need for "stories with negative overtones, such as conflict, tragedy, chaos, or suffering" (Harcup 2009)-which we here include in the news sub-class "bad news". In addition, the need for "stories about issues, individuals, groups, businesses, industries, places, regions and nations perceived to be relevant to the audience" (Harcup 2009), which we group under "local news", explains the lack of news regarding disasters beyond La Réunion.

Interestingly, once the eruption ended, reporting shifted from the hardships of the impacted community to sightseeing, view-point access and tourism. This fits the entertainment role of the tabloid, being Harcup's (2009) news value 6 (travel and nature pieces). This can be also be seen as a reaction to the recovery and rehabilitation stages of a natural disaster, where trying to get back to normality include reinstating the essential infrastructure, key social structures and businesses (Coppola 2015), where tourism is one of the key businesses in La Réunion. This now fits Harcup's (2009) news value 11 (stories in support of local issues, individuals, groups, businesses, industries, places, regions). Shifting the reporting to tourists may thus have served as reassurance that the island was getting back to "business as usual". However, the effect of increased tourism and impacted community resulted in both positive and negative impacts. For example, during the phase of ocean entry the eruption was portrayed as positive for the restaurants, especially those on the road to the southern viewing site, 
whose business was up 20\% (Ponin-Ballom 2007). However, for others the result was negative, especially the fishing industry who were faced with shoals of dead fish, thus prompting the 9 April headline:

"The restaurants laugh and the fishermen cry".

The fisherman thus treated the effects of hot water destroying the fish population on which their livelihood depended with defeatism and resignation, as revealed by quotes such as (Ponin-Ballom 2007):

- "Fishing, it's over! It's not worth continuing";

- "I do not understand why young people are encouraged to do this job as it is not a profession with a future";

- "The fishermen bring few fish. Not even enough to pay for the bait"

However, in general the information appearing in the reports was correct, reliable and valid, there appearing to be little distortion or credibility problems. This, to a large degree, was due to the appropriate and correct use of information sources by specialist journalists who knew their subject and knew where to go to obtain correct, reliable and valid information.

\section{Information sources}

JIR journalists used five main information sources to support their reporting of the April 2007 eruption:

1. Newspaper archives (e.g., "see yesterday's edition");

2. Scientific work and reference books;

3. Government agency communiqués;

4. OVPF website and information, or activity bulletins; and

5. Verbal histories.

In terms of OVPF website- and bulletin-derived information, tremor plots provided by OVPF were frequently published in the JIR, especially during the onset and end of activity, as well as during phases of summit instability. Scientific work and reference books were used especially to support background information pieces regarding the phenomena and their effects, with the $\mathrm{PhD}$ thesis of Patrick Bachélery (1981), for example, being used for explanations of pit crater instability at the Cratère Dolomieu. In terms of verbal (interview-based) accounts, four main sources were used:

1. For activity information, OVPF and Université de La Réunion staffs were used, with Observatoire Réunionais de l'Air (ORA) sources being cited for atmospheric effects. Biologists associated with La
Maison du Volcan and the Aquarium de La Réunion (La Réunion's main outreach centers for Earth and Ocean sciences, respectively) were used for ocean water effects, and medical experts were approached for health effects.

2. Government officials (the prefecture, the mayor, chamber of agriculture) were cited for response plans and decisions, although often a spokesperson was used.

3. The police, fire department, hospitals, forestry workers, the division of highways and public access, school principals and priests were quoted regarding hands-on response and community needs.

4. The resident population and local businesses were quoted for community and economic impacts during the eruption, with tourists and sightseers becoming the dominant source after the eruption.

Overall, the most frequently used group was the resident population, followed by observers (i.e., volcanologists), with decision makers, responders and business people being quoted in roughly equal measure; tourists and sightseers being the least used source (Fig. 9a). Sources used appear to have been selected according to the response theme being considered, so that OVPF (observers) was used for activity descriptions, decision makers for the response, and resident population for the actual impacts and effects. For example, when a journalist was denied access to the eruption site the quote in the following text named the police as being responsible for enforcing exclusion zones (Anon 2007n):

"Two gendarmes (policemen) refused our vehicle access at a first checkpoint on the St. Rose side last night. One of the men in blue, without even looking at the press card that we presented him, said that the card does not serve as authorization from the prefecture. 'It is the same as if you have you had presented me a fishing permit, and that is useless here', (he said)."

Roles between information providers, decision makers and responders were also clearly delineated. For example, regarding the evacuation of Le Tremblet, in a statement given on page 14 of JIR on 5 April 2007 the prefecture was quoted as stating:

"The decision will be taken in light of renewed seismicity on the southeast flank of 'L'Enclos'."

The use of information sources with time followed the prominent theme of the activity-type being reported (Fig. 9b). During the phase of concern regarding gas impacts (4-6 April) the director of ORA was regularly 

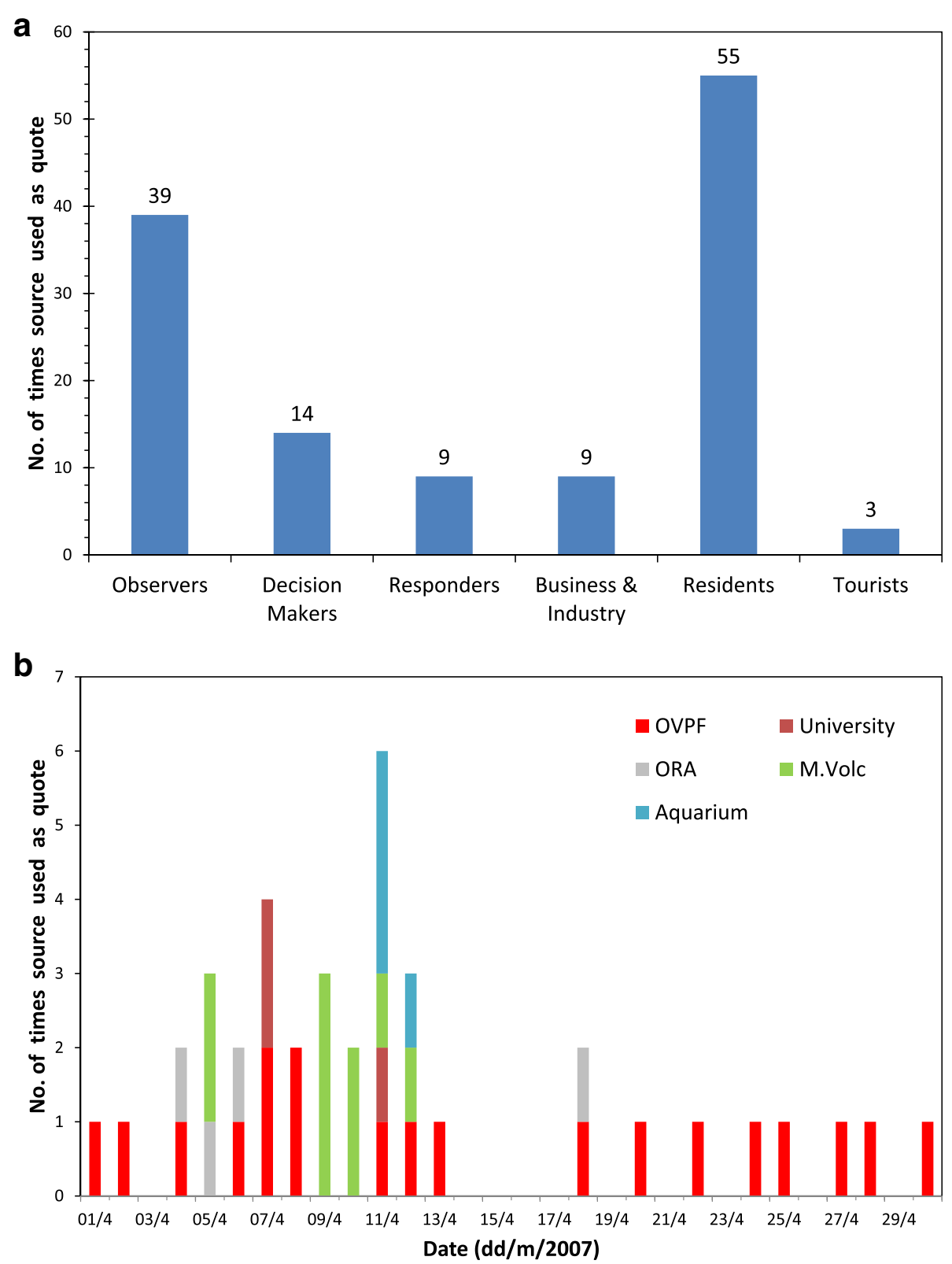

Fig. 9 a Number of times a particular "information-provider" type was quoted in volcano hazard related reporting in JIR during April 2007. b Number of times each "information-provider" type was quoted in volcano hazard related reporting in JIR during April 2007 broken out by provider

quoted, and marine biologists from La Maison du Volcan and The Aquarium de La Réunion were used during the period of fish mortality due to high water temperatures following ocean entry of lava flows (5-12 April). OVPF representatives were quoted regularly throughout the month of April (Fig. 9b), although there was a hiatus between 13 and 18 April, and after 18 April quotations from OVPF were a little more sporadic. Journalists did, however, continue to use and quote accurately from OVPF bulletins.

\section{The journalists}

Our analysis highlights the quality of hazard reporting that can be achieved by a dedicated journalist with a specialty in, and deep understanding of, the hazard to be reported. Reporting on the eruption was covered by 11 named journalists (A through E in Fig. 10). These journalists contributed 69 reports; with a further 22 being authored by anonymous (or not named) writers (Anon in Fig. 10). Three journalists (A, B and D, Fig. 10) contributed 47 of the reports appearing in April 2007. If we 


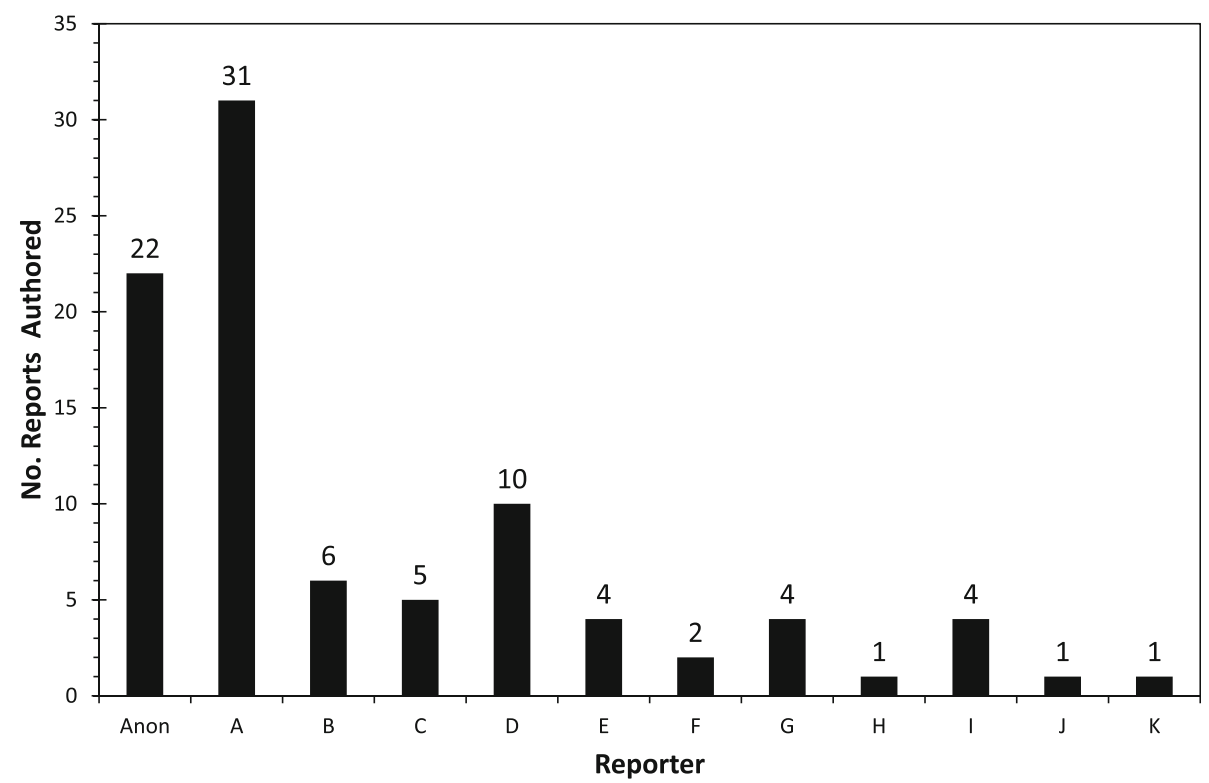

Fig. 10 Number of times each journalist published in JIR during April 2007

remove the anonymous category, this means that three journalists contributed $68 \%$ of the published material, with journalist A accounting for $45 \%$ of the material. While journalist A was largely responsible for reporting on volcanic activity, journalists B and D focused on evacuation of Le Tremblet and the subsequent recovery. Journalist E, instead, focused entirely on gas impacts. Some information, for example regarding ash fall or ocean entry was late in appearing, but when it did appear it was technically correctly and soberly worded; the information for viewing ocean entry in safety, for instance, being a translation of the schematics given by Johnson et al. (2000) (JIR, 28 April 2007, no. 18,373, p. 9).

In terms of report content, it was clear that each of these journalists knew their subject and, just as importantly, the local community. Vitally, they knew-from experience:

1. Where to go for correct, quality and up-to-the-minute information, and

2. Who to talk to.

Impressively, all predictive statements reported regarding the activity or response carried common-language uncertainty caveats as outlined by Harris (2015b), and the writing style was factual. Reports lacked exaggeration, omission or bias, and included correct definitions and sober advice (e.g., Table 1).

\section{Lessons for volcanologists}

By following reporting of a natural hazard in the media we can understand how important information is relayed to communities, what type of information is communicated and, thus, how we can work to develop and improve this communication portal. In the case study followed here, the progression of reporting through the eruption reflected the evolution of the hazard types, although there were differences in the reporting of familiar hazards and unfamiliar hazards. Following an event in such a way is an opportunity for volcanologists to track how an event is being reported so that we can respond with clarifying information to help communities if necessary. In some cases, the need can be pre-empted. For example, we found that there were delays in reporting of unfamiliar hazards, so such hazards could be identified and information provided to the media as soon as the need arises. This includes, for example, pre-empting Blong's (1984) "avoidable" hazards that could reduce visitor (tourist) risk. In this regard, setting up a press office that follows, and responds to, the news during a volcanic emergency is imperative. Better, the press office will already have a good relationship with the media source so that outreach communications are well-received, presented in a language that is immediately useful, and are issued on the basis of journalistic need. In doing this, the French term "vulgarisation" may be appropriate, i.e., we need to rephrase the knowledge of the specialists into a form that is accessible to the non-specialist (Le Petit Robert 2017).

\section{Protocols: A perspective from OVPF}

Nevertheless, we need to be careful about what we say and follow protocol (IAVCEI 1999; Giordano et al. 2016). 
Currently, in France, the ORSEC (Organisation de la Réponse de SEcurité Civile) plan clearly outlines the rules of communication, where communications from OVPF go upwards through the communication pyramid in a one voice style from the Scientist-in-Charge (SIC) through the local authority charged with managing the response, this being the préfecture (Harris et al. 2017). The good working relationship that has been developed between the OVPF and the prefecture is based on trust, and this has resulted in OVPF having also been given permission to communicate directly with the media-but while remaining factual in any such communication. This gentleman's agreement does, though, have a limit-this being in the case of exceptional events.

The 2007 eruption qualified as an exceptional event not only in terms of intensity but also, as described here, in terms of phenomenon witnessed by the impacted population. It was the first time since island settlement in the seventeenth century (Vaxelaire 2012) that cyclones and volcanic activity were visible at the same time with such violence and with such consequences. New experiences included:

- Emission of unusually fast and voluminous lava flows that very quickly cut communication routes between isolated communities, and caused communications to be severed for many months, resulting in a need to re-establish communication links-in spite of burial by up to $50 \mathrm{~m}$ of lava;

- Emission of $\mathrm{SO}_{2}$ plumes and generation of acid rain, leading to a need to evacuate schools and seek hospital treatment for students;

- Tephra fallout on proximal populations, and a need to protect and evacuate communities near the eruptive fissure;

- Caldera collapse, ash plumes, volcanic lightening, aviation hazards, and prohibition of over flights;

- Ocean entry of lava, dead fish on the ocean surface, and problems for the fishing industry;

- Intervention by military forces (the Gendarmerie) and the need for presence of a psychological care unit and the Red Cross in local communities.

All of these events occurred in the space of just three weeks. In addition, the 2007 eruption was the first case of its kind to trigger the whole chain of hazard management on La Réunion. This chain had been used to dealing with low intensity effusive eruptions that had dominated activity since the creation of OVPF in 1979. Indeed, such low intensity activity had dominated activity since initial settlement of the island, and so formed the population's only experience of volcanic eruptions. The "surprises" presented by the high intensity of, and variety of activity types associated with, the 2007 eruption was thus something of a shock. This shock resulted in a short circuit of the communication plan which, thus, failed. As a result, it is now written into the ORSEC plan that, if such an eruption occurs today, only the prefecture can provide communication upwards through the system towards the impacted population and the media.

As stated above, OVPF does have permission to respond to approaches by journalists. OVPF also provides eruption reports and updates via its website, and does have a very good relation with journalists both at JIR, Le Quotidien and freelance. However, for unusual and usual eruptions at Piton de la Fournaise, it would be beneficial to better manage communication between the observatory and the media by setting up a formal protocol. The establishment of a "press briefing" system using modern techniques-such as video conferencing-would be ideal, where the frequency and timing of briefings would depend on the intensity and type of activity, as well as changes in the eruption character. Such a briefing would require a synthesis of scientific, technical and observational information, as gathered by the observatory team member, to then be communicated during a crisis in a manner useful to the press. At OVPF, such a task could only be completed by the SIC, which is onerous given the numerous surveillance and reporting tasks required of the SIC during a crisis. Thus, during the eruptions of 2009 and 2010, this task was charged to a dedicated communication officer. This delegation was essential in ensuring adequate press briefing from such a small observatory team responding to a crisis and charged with many more urgent surveillance and civil protection-orientated reporting tasks.

\section{Media briefing support}

Media briefing needs to be supported by on-line information updates, newsletters and fact sheets. A nice example is the "Viewing Hawai'i's Lava Safely-Common Sense is Not Enough" fact sheet prepared by Johnson et al. (2000). The risk-avoidance advice for the bench collapse segment of this pamphlet was translated and reproduced in JIR on 28 April 2007 (Anon 2007o). However, this advice only appeared at the end of the eruption (on the 25th day), when the ocean entry had been active since the first day of the eruption. Indeed, in spite of continuous activity at the ocean entry since the first day of the eruption, the ocean entry itself was only reported, as a primary focus, only after the 8th day of the eruption. This indicates that journalists were ready to communicate such information, but needed time to find (and translate) the information. However, the type of hazard reported, and the information content of the reporting, depended very much on the type of impact felt and witnessed on any particular day, evolving 
through time as the reporter played catch-up with a fluid event scenario.

A real-time (and on-line) information-support task is one which has been pioneered by the Hawaiian Volcano Observatory through their daily, monthly and overview syntheses of activity, as well as provision of educational and explanatory material, through their website (https:// volcanoes.usgs.gov/observatories/hvo/). Posting of daily or twice-daily public-release newsletters containing activity updates, informed eye-witness accounts, risk recognition advice and process-based explanations pitched in lay-man's terms, but without giving opinion or interpretation, can only aid in the media briefing process (e.g., Johnson et al. 2000; Gill 2008; Poland et al. 2016). The media is then be free to access, use and credit, or link to, the resource (as was done by JIR on 28 April 2007 who credited the USGS—-specifically, Johnson et al. (2000) - as the source for their bench-collapse schematics). In this regard, OVPF already posts activity bulletins on their website, which are widely used by JIR-but only after they have been released by the prefecture. However, the OVPF bulletins are purely factual (giving times, locations and events) and do not contain any advice to those visiting a dangerous site, or phenomenological explanations regarding the nature of the risks, such as those given in Johnson et al. (2000). The OVPF currently needs the authorization of the prefecture to implement such a system. However, direct communication of newsletters to the media (which would be a time saver, as it would cut out the time needed for higher-level approval), coupled with the will of the media to implement information contained within newsletters from the OVPF, would pre-empt the journalists' need for material, and potentially improve the quality and timeliness of hazard information appearing in the media. In all, such protocols would increase our ability to educate the public regarding hazard, risk and mitigation.

\section{Conclusion}

Generally, reporting of the April 2007 eruption of Piton de la Fournaise in JIR can be viewed as close to a blueprint for hazard communication through a newspaper. The April 2007 eruption and its effects received high volume-news status, appearing on the front page as each new eruptive phase and associated hazard unfolded. This was due to the fact that a volcanic eruption, especially one which impinges on the local population, fits many (if not all) of the tabloid-newspaper news values. Reporting was accurate, well-supported and researched, and followed the evolution of the eruption, reviewing each new hazard as it evolved, with quotes mainly expressing warning, followed by alerts and impacts, and then response. It was, thus, an exceedingly useful educative tool.

In terms of a database and information source for natural hazards, when tabloid newspapers are involved, the local newspaper is an enormous and valuable resource. If tabloid sensationalism is removed-as is the aim of a traditional content analysis (e.g., Berelson 1952: Holsti 1969; Neuendorf 2002)-then useful information can be extracted and communicated. However, to avoid problems of error and loss of credibility, reporting needs to be tasked to dedicated journalists who are known and trusted by their sources and who, in turn, know and trust those same sources. For successful, credible, information dissemination through the newspaper the journalist needs to know where to go to obtain appropriate information before the hazard begins to impact, and the responders need to know who to contact in the press when the same hazard impacts a population. In the case studied here, the fact that a few dedicated and well-informed journalists with a strong background in their reporting area were charged with reporting on each event meant that a correct and detailed chronology was laid out. Each journalist was a specialist in their field, knowing where to go to find the correct data, facts and statements, and knowing how to shift their reporting between lava, gas, air-fall, ocean-entry, and collapse as the eruption evolved. These good reporting protocols applied by JIR resulted in dissemination of correct, appropriate and quality information regarding the various volcanic hazards witnessed during the April 2007 eruption of Piton de la Fournaise.

\section{Additional files}

Additional file 1: Hazards reported in Le Journal de L'ile: March - May 2007 (XLSX 24 kb)

Additional file 2: Local Volcanic Hazards reported in Le Journal de L'ile: March - May 2007 (XLSX 79 kb)

\section{Acknowledgements \\ We thank Francois Martel-Asselin for answering our many questions about reporting during the eruption of April 2007. We are also exceedingly grateful to Philippe Le Claire (Director of the JIR) for granting us permission to repro- duce JIR material and front pages to support this study. Two anonymous reviewers, the associate editor (Ilan Kelman), and the editor-in-chief (Jan Lindsay) provided excellent advice on how to better communicate this work. This is ANR-LAVA contribution no. 2.}

\section{Funding}

This work was funded by the Agence National de la Recherche (ANR: www.agence-nationale-recherche.fr) through project ANR-LAVA (ANR Program: DS0902 2016; Project: ANR-16 CE39-0009, Link: www.agencenationale-recherche.fr/?Project=ANR-16-CE39-0009).

\section{Availability of data and materials}

Raw data used here were PDF copies of the newspaper "Le Journal de L'lle de La Réunion" (JIR). These PDFs are available (for purchase) from http:// www.clicanoo.re/Journal-en-pdf-archives.html (this is now - 21/05/2018 https://www.payandread.fr/4DACTION/NewSwitchPublication?publicationID=18). All derived statistics measured from these PDFs were entered first into a code book, and then collated into two spreadsheets. There two data summary collations, on which all graphs, tables and statements here are based, are presented as EXCEL spreadsheets in the electronic supporting material. These collations are: (i) the content analysis solely for volcanic events recorded during 
March-May 2007 (Piton April 2007 - Content Analysis - All Hazards.xIsx), and (ii) the content analysis for all natural hazards reported during March-May 2007 (Piton April 2007 - Content Analysis - All Hazards.xIsx (Additional file 1)). Also in the electronic supporting material are the results of the Tabloid analysis (Tabloid Test.xIsx)(Additional file 2) which was applied to all newspapers entered in the spreadsheet and as purchased as PDF copy from each newspaper website.

\section{Authors' contributions}

All authors have reviewed this manuscript and contributed to its content. All authors read and approved the final manuscript.

\section{Competing interests}

The authors declare that they have no competing interests.

\section{Publisher's Note}

Springer Nature remains neutral with regard to jurisdictional claims in published maps and institutional affiliations.

\section{Author details}

${ }^{1}$ Université Clermont Auvergne, CNRS, IRD, OPGC, Laboratoire Magmas et Volcans, 6 Avenue Blaise Pascal, 63178 Aubière, France. ${ }^{2}$ Observatoire Volcanologique du Piton de la Fournaise, Institut de Physique du Globe de Paris, Sorbonne Paris Cité, CNRS, Université Paris Diderot, F-75005 Paris, France. ${ }^{3}$ Laboratoire GéoSciences Réunion, Université de La Réunion, Institut de Physique du Globe de Paris, Sorbonne Paris Cité, CNRS, F-97744 Saint Denis, France.

Received: 29 November 2017 Accepted: 14 May 2018

Published online: 31 May 2018

\section{References}

Amiotte S Nuages de soufre sur l'Ouest et le Sud. Le Journal de L'lle de La Réunion (jeudi 5 Avril 2007). 2007a;No. 18350:15.

Amiotte S Une nocivité négligée. Le Journal de L'lle de La Réunion (mercredi 4 Avril 2007). 2007b;No. 18349: 12.

Amiotte S "Le soufre est l'ennemi de l'homme." Le Journal de L'lle de La Réunion (samedi 7 Avril 2007). 2007c; No. 18352: 6.

Anon Gamede nourrit la hausse des prix. Le Journal de L'lle de La Réunion (samedi 19 Mai 2007). 2007a;No. 18393: 21.

Anon Le volcan à nouveau accessible au public. Le Journal de L'lle de La Réunion (mercredi 7 Mars 2007). 2007b;No. 18321: 9.

Anon Eruption annoncée. Le Journal de L'Ile de La Réunion (samedi 24 Mars 2007). 2007c; No. 18338: 6.

Anon Toujours dans l'attente d'une suite à l'éruption. Le Journal de L'lle de La Réunion (lundi 2 Avril 2007). 2007d; No. 18347: 8.

Anon LE VOLCAN DEVIENT FOU. Le Journal de L'lle de La Réunion (mercredi 4 Avril 2007). 2007e; No. 18349: 1

Anon L'éruption provoque des pluies acides sur Maurice. Le Journal de L'lle de La Réunion (jeudi 12 Avril 2007). 2007f; No. 18357: 8.

Anon Nouvel assaut des coulées dans le Grand Brûlé. Le Journal de L'lle de La Réunion (dimanche 15 Avril 2007). 2007g; No. 18360: 5.

Anon Le cratère Dolomieu, un gouffre de 300 mètres de profondeur ! Le Journal de L'lle de La Réunion (dimanche 8 Avril 2007). 2007h;No. 18353: 35.

Anon Une éruption intarissable. Le Journal de L'lle de La Réunion (mardi 10 Avril 2007). 2007i;No. 18355: 7.

Anon Le Tremblet aux portes de l'enfer. Le Tremblet évacué pour rien. Le Journal de L'lle de La Réunion (samedi 7 Avril 2007). 2007j;No. 18352: 9.

Anon Malaise cardiaque fatal en rentrant du volcan. Le Journal de L'lle de La Réunion (mercredi 9 Mai 2007). 2007k;No. 18383: 7.

Anon Des effondrements en profondeur. Le Journal de L'lle de La Réunion (dimanche 20 Mai 2007). 2007l;No. 18394: 5

Anon "Ces gens ont besoin de relations humaines". Le Journal de L'lle de La Réunion (samedi 26 Mai 2007). 2007m;No. 18400: 24.

Anon "Carte de presse = carte de pêche !". Le Journal de L'lle de La Réunion (jeudi 5 Avril 2007). 2007n;No. 18350: 17.

Anon "Quand la lave craque pour l'océan". Le Journal de L'lle de La Réunion (samedi 28 Avril 2007). 2007o;No. 18373: 9

Bachélery P. Le Piton de la Fournaise (lle de la Réunion). Clermont Ferrand: Etude volcanologique, structural et pétrologique, Ph.D. thesis, Univ. Clermont Ferrand II; 1981.
Bachèlery P, Saint-Ange F, Villeneuve N, Savoye B, Normand A, Le Drezen E, Barrère A, Quod J-P, Deplus C. Huge lava flows into the sea and caldera collapse, April 2007, piton de la Fournaise volcano. In: IAVCEl third workshop on collapse calderas abstracts volume. France: La Reunion; 2010. p. 73-4.

Berelson B. Content analysis in communications research. New York: Free Press; 1952. p. 220

Blong RJ. Volcanic hazards: a sourcebook on the effects of eruptions. Sydney: Academic Press; 1984. p. 424

Burt CC. Extreme weather. New York: WW Norton \& Co; 2007. p. 303.

Cohen BC. The press and foreign policy. Princeton: Princeton University Press; 1963. p. 288

Conboy M. Journalism: a critical history. London: Sage Publications; 2004. p. 246.

Conboy M. Journalism in Britain: a historical introduction. Los Angeles: Sage Publications; 2011. p. 230.

Coppola D. Introduction to International Disaster Management, 3rd Edition. Butterworth-Heinemann (Oxford, UK). 2015. p. 760.

Coppola D, Piscopo D, Staudacher T, Cigolini C. Lava discharge rate and effusive pattern at piton de la Fournaise from MODIS data. J Volcanol Geotherm Res. 2009;184(1-2):174-92. https://doi.org/10.1016/j.jvolgeores. 2008.11.031.

Davies N. Flat earth news: an award-winning reporter exposes falsehood, distortion and propaganda in the global media. London: Vintage; 2009. p. 420.

Dupuis A Gamede sème la pagaille à Gillot. Le Journal de L'lle de La Réunion (mardi 25 Février 2007). 2007a;No. 18314: 7.

Dupuis A Bain de minuit pour le Piton de la Fournaise. Le Journal de L'lle de La Réunion (mardi 3 Avril 2007). 2007b;No. 18348: 10.

Dupuis A La guerre du feu et de l'eau. Le Journal de L'lle de La Réunion (mercredi 4 Avril 2007). 2007c;No. 18349: 10.

Dupuis A Le Tremblet aux portes de l'enfer. Le Tremblet évacué pour rien. Le Journal de L'lle (samedi 7 Avril 2007). 2007d;No. 18352: 6.

Frasson-Botton Les mystères des abysses à portée de main. Le Journal de L'lle de La Réunion (mardi 10 Avril 2007). 2007;No. 18355: 10-11.

Froger J-L, Famin V, Cayol V, Augier A, Michon L, Lénat J-F. Time-dependent displacements during and after the April 2007 eruption of Piton de la Fournaise, revealed by interferometric data. J Volcanol Geotherm Res. 2015:296:55-68

G.L. La population partagée entre inquiétude et fascination. Le Journal de L'lle de La Réunion (vendredi 6 Avril 2007). 2007:18351:18.

Gill J. Communicating forecast uncertainty for service providers. WMO Bull. 2008; 57(4):237-43.

Giordano G, Bretton R, Calder E, et al. Toward IAVCEI guidelines on the roles and responsibilities of scientists involved in volcanic hazard evaluation, risk mitigation, and crisis response. Bull Volcanol. 2016;78(31) https://doi.org/10. 1007/s00445-016-1021-8.

Guzzetti F, Cardinali M, Reichenbach P. The AVI project: a bibliographical and archive inventory of landslides and floods in Italy. Environ Manag. 1995;18(4): 623-33.

Guzzetti F, Reichenbach P, Cardinali M, Ardizzone F, Galli M. The impact of landslides in the Umbria region, Central Italy. Nat Hazards Earth Syst Sci. 2003;3:469-86

Harcup T. Journalism: principles and practice (second edition). Los Angeles: Sage. 2009. p. 244

Harris AJL. Forecast communication through the newspaper part 1: framing the forecaster. Bull Volcanol. 2015a;77:29. https://doi.org/10.1007/s00445-0150899-x.

Harris AJL. Forecast communication through the newspaper part 2: perceptions of uncertainty. Bull Volcanol. 2015b;77:30. https://doi.org/10.1007/s00445-0150902-6.

Harris AJL. Basaltic lava flow hazard. In: Papale P, editor. Volcanic hazards, risks and disasters. Amsterdam: Elsevier; 2015c. p. 17-46.

Harris AJL, Gurioli L, Hughes EE and Lagreulet S Impact of the Eyjafjallajökull ash cloud: a newspaper perspective. J Geophys res. 2012;117(B00C08): doi:https:// doi.org/10.1029/2011JB008735.

Harris AJL, Lanfranco M. Cloudburst, weather bomb or water bomb? A review of terminology for extreme rain events and the media effect. Weather. 2017; 72(6):155-63.

Harris AJL, Villeneuve N, Di Muro A, Ferrazzini V, Peltier A, Coppola D, Favalli M, Bachèlery P, Froger JL, Gurioli L, Moune S, Vlastélic I, Galle B, Arellano S. Effusive crises at piton de la Fournaise 2014-2015: a review of a multinational response model. J Appl Volcanol. 2017:1-29. https://doi.org/10.1186/ s13617-017-0062-9. 
Heggie TW. Reported fatal and non-fatal incidents involving tourists in Hawail volcanoes National Park, 1992-2002. Travel Med Infect Dis. 2005;3:123-31.

Heggie TW, Heggie TM. Viewing lava safely: an epidemiology of hiker injury and illness in Hawaii volcanoes national park. Wilderness Environ Med. 2004;15:77-81.

Hilker N, Badoux A, Hegg C. The Swiss flood and landslide damage database 1972-2007. Nat Hazards Earth Syst Sci. 2009;9:913-25.

Holsti OR. Content analysis for the social sciences and humanities. AddisonWesley, Reading (MA). 1969. p. 235

Horrie C. Tabloid nation: from the birth of the daily mirror to the death of the tabloid. London: André Deutsch; 2003. p. 256.

IAVCEI - Subcommittee for Crisis Protocols. Professional conduct of scientists during volcanic crises. Bull Volcanol. 1999;60:323-34

Johnson J, Brantley SR, Swanson DA, Stauffer PH, Hendley JW. Viewing Hawai'i's lava safely_common sense is not enough. USGS Fact Sheet. 2000:152-00. 4 p

Krippendorff K. Content Analysis: An Introduction to its Methodology. The Sage COMMTEXT Series 5. Beverly Hills: Sage. 1980. p. 189

Lauret T. D'étranges poissons font surface. Le Journal de L'lle de La Réunion (lundi 9 Avril 2007). 2007;No. 18354: 8

Lenormand R. Les recherches du corps de Willy. Le Journal de L'lle de La Réunion (dimanche 11 Mars 2007). 2007:No. 18325: 6.

Leyral P. Le Tremblet se prépare à évacuer. Le Journal de L'lle de La Réunion (jeudi 5 Avril 2007). 2007a;No. 18350: 14.

Leyral. Le Tremblet se réveille sous les cendres et dans la crainte. Le Journal de L'lle de La Réunion (jeudi 6 Avril 2007). 2007b;18351:14.

Leyral P. Une route sur la lave d'ici deux mois. Le Journal de L'lle de La Réunion (dimanche 8 Avril 2007). 2007c;No. 18400: 13

Leyral P. Les exilés du volcan ont pu enfin dormir. Le Journal de L'lle de La Réunion (samedi 26 Mai 2007). 2007d;No. 18353: 14.

Leyral P, Lutton J-P, François J-C. Le Tremblet évacué pour rien. Le Journal de L'Ile de La Réunion (samedi 7 Avril 2007). 2007a;No. 18352: 7.

Leyral P, Lutton J-P, François J-C. "Ce n'est plus un volcan, c'est un monstre". Le Journal de L'lle de La Réunion (samedi 7 Avril 2007). 2007b;No. 18352: 10.

Leyral P, Martel-Asselin, F. Deux sites en cours de sécurisation. Le Journal de L'lle de La Réunion (mardi 24 Mars 2007). 2007;No. 18369: 4.

Lutton J-P. Indemnisation expresse à un mois des élections. Le Journal de L'Ile de La Réunion (mardi 13 Mars 2007). 2007a;No. 18327: 17.

Lutton J-P. Après l'enfer, la désolation. Le Journal de L'lle de La Réunion (dimanche 8 Avril 2007). 2007b;No. 18353: 12.

Lutton J-P. Le Tremblet retrouve son calme dans un décor lunaire. Le Journal de L'Ile de La Réunion (mardi 10 Avril 2007). 2007c;No. 18355: 9.

Maier SC. Accuracy matters: a cross-market assessment of newspaper error and credibility. J\&MC Quarterly. 2005;82(3):533-51.

Martel-Asselin F. Vers une réouverture de l'enclos au public. Le Journal de L'lle de La Réunion (mardi 6 Mars 2007). 2007a;(18320):8.

Martel-Asselin F. Un spectacle d'une époque révolue? Le Journal de L'lle de La Réunion (mercredi 7 Mars 2007). 2007b;(18321):9.

Martel-Asselin F. Éruption de plus en plus en vue. Le Journal de L'Ile de La Réunion (mardi 27 Mars 2007). 2007c:(18341):8.

Martel-Asselin F. Une centaine de séismes par jour. Le Journal de L'lle de La Réunion (mercredi 28 Mars 2007). 2007d;(18342):6.

Martel-Asselin F. Les séismes s'intensifient. Le Journal de L'lle de La Réunion (jeudi 29 Mars 2007). 2007e;(18343):6.

Martel-Asselin F. Le volcan en éruption. Le Journal de L'lle de La Réunion (samedi 31 Mars 2007). 2007f:(18345):4.

Martel-Asselin F. Nouvelle éruption possible, mais où ? Le Journal de L'lle de La Réunion (diamanche 1 Avril 2007). 2007g;(18346):4.

Martel-Asselin F. Le volcan devient-il fou?. La guerre du feu et de l'eau. Le Journal de L'lle de La Réunion (mercredi 4 Avril 2007). 2007h:(18349):11

Martel-Asselin F. Le démêlé des cheveux de Pélé. Le Journal de L'lle de La Réunion (jeudi 5 Avril 2007). 2007i;(18350):16.

Martel-Asselin F. Une activité démentielle. Le Journal de L'lle (vendredi 6 Avril 2007). 2007j;(18351):16.

Martel-Asselin F. Un risque, pas une menace. Le Journal de L'Ile de La Réunion (jeudi 5 Avril 2007). 2007k;(18350):15

Martel-Asselin F. Un gouffre à la place du Dolomieu. Le Journal de L'lle de La Réunion (samedi 7 Avril 2007). 2007l;(18352):5

Martel-Asselin F. Le cratère Bory à son tour menacé. Le Journal de L'lle de La Réunion (vendredi 13 Avril 2007). 2007m;(18358):10-1.

Martel-Asselin F. Le Tremblet souffle un peu. Le Journal de L'lle de La Réunion (lundi 9 Avril 2007). 2007n;(18354):9.
Martel-Asselin F. Une éruption exceptionnelle. Le Journal de L'lle de La Réunion (mercredi 11 Avril 2007). 2007o:(18356):14

Martel-Asselin F. Le volcan joue les prolongations. Le Journal de L'lle de La Réunion (jeudi 12 Avril 2007). 2007p:(18357):8.

Martel-Asselin F. Reprise d'activité au cratère Dolomieu? Le Journal de L'lle de La Réunion (lundi 16 Avril 2007). 2007q;(18361):6.

Martel-Asselin F. Une nouvelle éruption possible. Le Journal de L'lle de La Réunion (mercredi 2 Mai 2007). 2007r;(18376):6.

Martel-Asselin F. Une nouvelle éruption possible. Le Journal de L'lle de La Réunion (jeudi 3 Mai 2007). 2007s;(18377):12.

Martel-Asselin F. Quatre points de vue sur les coulées. Le Journal de L'lle de La Réunion (samedi 5 Mai 2007). 2007t;(18379):9.

Mathien M. La presse quotidienne régionale. Paris: Presses Universitaires de France; 1986. p. 127.

McCombs M. Setting the agenda. Malden: Polity Press; 2014a. p. 209.

McCombs M. Setting the agenda. 2nd ed. Cambridge: Polity Press; 2014b. p. 209.

McCombs M, Shaw DL. Agenda-setting function of mass media. Publ Opin Q. 1972;36(2):176-87.

Météo-France Février. Bulletin climatique mensuel départemental outre-mer, 974 Réunion, BCMOM_974_200702. 2007; 1 p.

Neuendorf KA. The content analysis guidebook. Thousand Oak: Sage. 2002. pp. 301

P.M. La solidarité prend le relais. Le Journal de L'lle de La Réunion (mercredi 4 Avril 2007). 2007a;(18349):13.

P.M. Même terminée, l'éruption fascine toujours. Le Journal de L'lle de La Réunion (dimanche 6 mai 2007). 2007b;(18380):7.

Peltier A, Staudacher T, Bachèlery P, Cayol V. Formation of the April 2007 caldera collapse at piton de La Fournaise volcano: insights from GPS data. J Volcanol Geotherm Res. 2009;184:152-63.

Petrucci O, Pasqua AA, Gullà G. Landslide damage assessment using the support analysis framework (SAF): the 2009 landsliding event in Calabria (Italy). Adv Geosci. 2010;26:13-7.

Poland M, Orr TR, Kauahikaua. et al. The 2014-2015 Pahoa lava flow crisis at Kilauea volcano, Hawaii: disaster avoided and lessons learned. GSA Today. 2016;26(2): doi: https://doi.org/10.1130/GSATG262A.1.

Ponin-Ballom J. Les restaurateurs rient et les pêcheurs pleurent. Le Journal de L'lle de La Réunion (lundi 9 Avril 2007). 2007;No. 18354: 10.

Quetelard H, Bessemoulin P, Cerveny RS, Peterson TC, Burton A, Boodhoo Y. World breaking rainfalls during tropical cyclone Gamede. Bull Am Met Soc. 2008:603-7.

Rhéty M, Harris A, Villeneuve N, Gurioli L, Medard E, Chevrel O, Bachélery P. A comparison of cooling-limited and volume-limited flow systems: examples from channels in the piton de la Fournaise April 2007 lava-flow field. Geochem Geophys Geosyst. 2017;18 https://doi.org/10.1002/2017GC006839.

Robert LP. Le Petit Robert de la langue française. Paris: SNL Le Robert; 2017. p. 2748.

Rooney D. Thirty years of competition in the British tabloid press: the mirror and the sun 1968-1998. In: Tulloch J, Sparks C, editors. Tabloid tails. Oxford: Rowman and Littlefield; 2000. p. 91-108.

Roult G, Peltier A, Taisne B, Staudacher T, Ferrazzini V, Di Muro A and the OVPF team. A new comprehensive classification of the Piton de la Fournaise activity spanning the 1985-2010 period. Search and analysis of short-term precursors from a broad-band seismological station. J Volcanol Geotherm Res. 2012;241-242:78-104

Séchet G. Chronique des aléas climatiques : La Météo en France de 1900 à nos jours. France: Herm. 2004. p. 288.

Staudacher T, Ferrazzini V, Peltier A, Kowalski P, Boissier P, Catherine P, Lauret F, Massin F. The April 2007 eruption and the Dolomieu crater collapse, two major events at piton de la Fournaise (La Reunion Island, Indian Ocean). J Volcanol Geotherm Res. 2009;184:126-37. https://doi.org/10.1016/j. jvolgeores.2008.11.005.

Staudacher T, Ruzié L, Peltier A. Historique des éruptions du Piton de la Fournaise de 1998 à 2007. St Denis: Graphica; 2008. p. 97.

Sterling R. The weather of Britain. London: Faber \& Faber. 1997. p. 306

T.L. Minatchy : "Bonjour les dégâts". Le Journal de L'Ile de La Réunion (samedi 7 Avril 2007). 2007a;(18352):11.

T.L. Le trémor se poursuit, le Dolomieu s'est stabilisé. Le Journal de L'lle de La Réunion (dimanche 8 Avril 2007). 2007b:(18353):10.

Técher N. 80000 foyers dans le noir et privés d'eau. Le Journal de L'lle de La Réunion (mardi 27 Février 2007). 2007;No. 18312: 8

Tulet $P$, Villeneuve N. Large scale modeling of the transport, chemical transformation and mass budget of the sulfur emitted during the April 2007 eruption of piton de la Fournaise. Atmos Chem Phys. 2011;11(9):4533-46. 
Vaxelaire D. L'histoire de La Réunion 1. Des origines à 1848. Saint-Denis: Édtions Orphie; 2012. p. 350.

Verrière P. L'effondrement du pont coupe le Sud en deux. Le Journal de L'lle de La Réunion (lundi 26 Février 2007). 2007;No. 18312: 6-7.

Vu HT, Guo L, McCombs ME. Exploring "the world outside and the pictures in our heads": a network agenda-setting study. J Mass Commun Quart. 2014;91: 669-86. https://doi.org/10.1177/1077699014550090.

Watson T, Hickman M. Dial M for Murdoch: news corporation and the corruption of Britain. London: Penguin; 2010. 339 p

Weber RP. Basic Content Analysis, Quant. Newbury Park: Sage. Appl. Soc. Sci. 1990:49(2nd ed):95

\section{Submit your manuscript to a SpringerOpen ${ }^{\odot}$ journal and benefit from:}

- Convenient online submission

- Rigorous peer review

- Open access: articles freely available online

- High visibility within the field

- Retaining the copyright to your article

Submit your next manuscript at $\gg$ springeropen.com 